\title{
Contribution of denitrification to nitrogen, carbon, and oxygen cycling in tidal creek sediments of a New England salt marsh
}

\author{
M. Robert Hamersley ${ }^{1,3, *}$, Brian L. Howes ${ }^{2}$ \\ ${ }^{1}$ Department of Biology, Woods Hole Oceanographic Institution, 45 Water St., Woods Hole, Massachusetts 02543, USA \\ ${ }^{2}$ School for Marine Science and Technology, University of Massachusetts, 706 S. Rodney French Blvd., New Bedford, \\ Massachusetts 02744-1221, USA
}

${ }^{3}$ Present address: School for Marine Science and Technology, University of Massachusetts, 706 S. Rodney French Blvd., New Bedford, Massachusetts 02744-1221, USA

\begin{abstract}
The contribution of denitrification to sediment metabolism was studied at 2 sites (muddy and sandy) in unvegetated tidal creek sediments from a small Cape Cod, USA, salt marsh receiving nitrate-enriched groundwater flows $\left(32 \mathrm{mmol} \mathrm{m}^{-2} \mathrm{~d}^{-1}\right)$. Simultaneous measurements of sediment $\mathrm{N}_{2}$, $\mathrm{CO}_{2}, \mathrm{O}_{2}$, and dissolved inorganic $\mathrm{N}$ fluxes were made over annual cycles. A total of $46 \%$ of the ammonium remineralized within the sediments was transformed to $\mathrm{N}_{2}$ by coupled nitrificationdenitrification $\left(D_{\mathrm{n}}\right)$. Denitrifying and nitrifying bacteria contributed 15 and $18 \%$ to total sediment C and $\mathrm{O}$ cycling, respectively. $\mathrm{C}, \mathrm{N}$, and $\mathrm{O}_{2}$ cycling rates were limited by both temperature and the availability of labile organic matter. Muddy sediment $\mathrm{C}$ content was twice that of sandy sediments, but was half as labile, resulting in similar mean metabolic rates between sediment types (mean muddy and sandy $\mathrm{O}_{2}$ consumption rates were 62 and $58 \mathrm{mmol} \mathrm{m}^{-2} \mathrm{~d}^{-1}$, respectively; $\mathrm{CO}_{2}$ production was 58 and $46 \mathrm{mmol} \mathrm{m}^{-2} \mathrm{~d}^{-1}$; and $D_{\mathrm{n}}$ was 5.4 and $\left.4.9 \mathrm{mmol} \mathrm{N} \mathrm{m}{ }^{-2} \mathrm{~d}^{-1}\right)$. Sediment $\delta^{13} \mathrm{C}(-18.5$ and $-20.8 \%$ ) and the molar $\mathrm{CO}_{2}: \mathrm{N}$ flux ratio (6.1) at both sites are consistent with a sediment metabolism based on algal rather than macrophytic biomass, and groundwater nitrate was the dominant source of $\mathrm{N}$ supporting algal growth. Annually, $D_{\mathrm{n}}$ accounted for $72 \%$ of total denitrification, with the remainder accounted for by water column-supported denitrification. Since all the denitrified $\mathrm{N}$ originated from groundwater nitrate, algal uptake must have initially out-competed denitrification for water column nitrate, but nearly half of this algal $\mathrm{N}$ was subsequently remineralized and denitrified.
\end{abstract}

KEY WORDS: Salt marsh · Denitrification · Sediment metabolism · Groundwater nitrogen

\section{INTRODUCTION}

Salt marshes in New England, USA, play significant roles in the coastal zone $\mathrm{N}$ cycle. Inorganic $\mathrm{N}$ availability limits salt marsh macrophyte and algal productivity, while high rates of microbial denitrification of $\mathrm{NO}_{3}{ }^{-}$to $\mathrm{N}_{2}$ gas in salt marsh sediments remove $\mathrm{N}$ from recycling pools (Sullivan \& Daiber 1974, Valiela \& Teal 1974, Howes et al. 1996). The physical structure of these salt marshes typically consists of intermittently flooded vegetated peats of the halophilic macrophytes
Spartina spp., and unvegetated tidal creek sediments that drain the marsh and comprise ca. $1 / 3$ of its total area (Valiela \& Teal 1979, Howes et al. 1996). Denitrification in these tidal creek sediments can intercept $\mathrm{N}$ as it flows from land to sea, limiting its availability to support primary production and eutrophication in coastal aquatic environments (Fujita et al. 1989, Harvey \& Odum 1990, Howes et al. 1996).

Terrestrial $\mathrm{N}$ inputs (primarily as $\mathrm{NO}_{3}{ }^{-}$from sewage disposal and agricultural runoff) dominate salt marsh $\mathrm{N}$ budgets in populated areas, and tidal creek sedi- 
ments are the primary site of contact with this overland- and groundwater-borne N (Sewell 1982, Valiela et al. 1990, Howes et al. 1996, Weiskel et al. 1996). Water column $\mathrm{NO}_{3}{ }^{-}$can support high levels of salt marsh productivity (Valiela \&Teal 1974, Havens et al. 2001). The accumulated organic matter forms the basis for detrital food chains and supports the dominant role played by anaerobic metabolism (including sulfate reduction and denitrification) in sediment carbon (C) turnover (Teal 1962, Jørgensen 1982, Howes et al. 1985). Water column $\mathrm{NO}_{3}{ }^{-}$contacting salt marsh tidal creek sediments may be retained by algal uptake, or lost through denitrification or tidal export. Retained

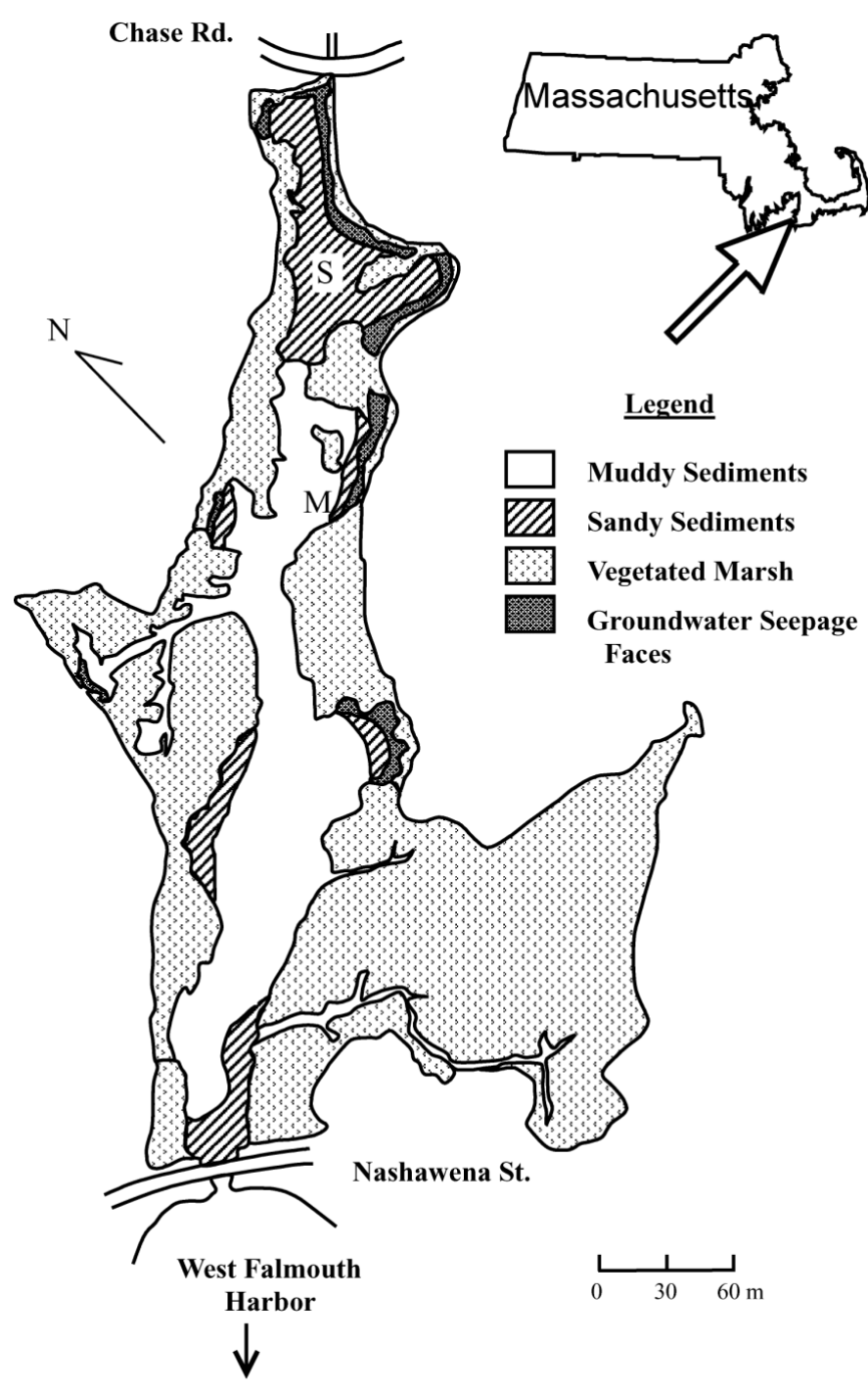

Fig. 1. Location of Mashapaquit Marsh within the sandy outwash aquifer of Cape Cod, Massachusetts, USA. Tidal exchange is with West Falmouth Harbor. Shaded areas indicate distribution of sediment types. S and $\mathrm{M}$ indicate the location of our sandy and muddy sampling sites, respectively algal $\mathrm{N}$ is subject to burial or export losses, or to remineralization as ammonium $\left(\mathrm{NH}_{4}{ }^{+}\right)$. Like $\mathrm{NO}_{3}{ }^{-}$, remineralized $\mathrm{NH}_{4}{ }^{+}$can either be retained by algal re-uptake, or lost through coupled nitrificationdenitrification $\left(D_{\mathrm{n}}\right)$ to $\mathrm{N}_{2}$.

The purpose of the present study was to determine the contribution of nitrification and denitrification to the overall fate of $\mathrm{N}, \mathrm{C}$, and $\mathrm{O}$ within the highly Nloaded sediments of a New England salt marsh. Simultaneous measurements were made of the fluxes of $\mathrm{N}_{2}$, $\mathrm{CO}_{2}, \mathrm{O}_{2}$, and dissolved inorganic $\mathrm{N}$ species across the sediment-water interface in laboratory incubations of intact tidal creek sediments. These measurements were carried out over 3 annual cycles in both sandy and muddy sediments. The source of the organic $\mathrm{N}$ supporting $D_{\mathrm{n}}$ was identified through the analysis of biogeochemical flux ratios and the isotopic signatures and characteristics of sediment $\mathrm{C}$.

\section{MATERIALS AND METHODS}

Study site. Mashapaquit Marsh (Cape Cod, USA; Fig. 1), a small (5.7 ha) salt marsh, was the subject of an earlier study using mass balance and hydrological methods to determine the fate of groundwater $\mathrm{NO}_{3}{ }^{-}$ inputs (Smith 1999). Mashapaquit Marsh exchanges with West Falmouth Harbor, a shallow embayment of Buzzards Bay, on the west side of Cape Cod, Massachusetts, USA. The wide, central, unvegetated creek is flushed by semi-diurnal tides of mean $1.2 \mathrm{~m}$ range, with nearly complete drainage during spring tides. The marsh receives freshwater flows from a 284 ha watershed of highly permeable glacial outwash deposits. Watershed flows are $2.2 \times 10^{6} \mathrm{~m}^{3} \mathrm{yr}^{-1}$, delivering a total freshwater $\mathrm{N}$ flux to the tidal creeks of 32 mmol $\mathrm{N} \mathrm{m}^{-2} \mathrm{~d}^{-1}$, of which $90 \%$ is in the form of $\mathrm{NO}_{3}{ }^{-}$. Over $90 \%$ of this influent $\mathrm{N}$ derives from wastewater disposal (68\% from a wastewater treatment facility and $22 \%$ from residential septic wastewater disposal).

Work was focused on a sandy (S) and a muddy (M) site at the upper end of the marsh, flooded areas receiving groundwater enriched in N (Smith 1999). Sediments (8 to $12 \mathrm{~cm}$ deep) were collected in glass core tubes $(8.8 \mathrm{~cm}$ diameter) in shallow water $(30 \mathrm{~cm})$ at low tide. The sediments were handled carefully to avoid disturbance of sediment structure or porewater substrate profiles. Sediment cores were immediately transported at in situ temperatures, and with headspace water aeration, to the laboratory $(1 \mathrm{~h})$. A $15 \mathrm{~cm}^{3}$ surface sediment sample (to $2 \mathrm{~cm}$ depth) was collected, stored in a dark container, and frozen for sediment pigmentcontent determination (see 'Analysis' section). Tidal creek sediments for sediment mapping were collected along 10 horizontal transects $(\mathrm{n}=82)$. 
Sediment flux. Metabolic rates were determined in dark incubations of intact sediments in closed chambers. A $\mathrm{N}_{2}$-free headspace increased sensitivity for denitrification measurements (Seitzinger et al. 1984). Parallel incubations of anaerobic microcosms (no nitrification-denitrification) were made to control for diffusion-driven $\mathrm{N}_{2}$ gas fluxes out of the sediments, and the potential introduction of atmospheric $\mathrm{N}_{2}$ into the chambers (Nowicki 1994). Denitrification and $\mathrm{O}_{2}$ fluxes were determined on 14 dates, with measurements of $\mathrm{CO}_{2}, \mathrm{NH}_{4}{ }^{+}$, and $\mathrm{NO}_{\mathbf{x}}{ }^{-}$flux on a subset of dates (Table 1). The sediments were incubated within the glass-core tubes used for collection (to minimize disturbance), and were carefully covered with $8 \mathrm{~cm}$ of half-strength seawater (mean salinity of Mashapaquit Marsh water). Filtered (0.22 $\mu \mathrm{m}$ Millipore), low- $\mathrm{NO}_{3}{ }^{-}$ $(<2 \mu \mathrm{M})$ headspace water was used to separate water column from benthic processes. Over the headspace water (stirred by externally driven magnets at $60 \mathrm{rpm}$ ) was a gas headspace $(\sim 10 \mathrm{~cm})$, either at a $80: 20 \%$ $\mathrm{He}: \mathrm{O}_{2}$ ratio (aerobic microcosms) or $100 \% \mathrm{He}$ (anaerobic microcosms). Headspace pressurization (1.3 atm) maintained positive chamber pressure (since internal pressure falls during incubation due to respiratory $\mathrm{O}_{2}$ depletion and dissolved $\mathrm{CO}_{2}$ accumulation), reducing the risk of atmospheric $\mathrm{N}_{2}$ influxes. The whole apparatus was sealed at the top and bottom with rubber stoppers held together in a press.

Headspace gasses and dissolved constituents were sampled daily for 4 consecutive days after the initial (3 d) rapid degassing of porewater-dissolved gas pools. $\mathrm{O}_{2}, \mathrm{CO}_{2}$, and $\mathrm{N}_{2}$ were determined immediately by gas chromatography (see below) of a $5 \mathrm{ml}$ gas sample withdrawn with a gas-tight valved syringe inserted through a flooded well in the top stopper. $\mathrm{NH}_{4}{ }^{+}$and dissolved $\mathrm{CO}_{2}$ analyses were performed immediately on a water sample withdrawn from a valved port through a $0.22 \mathrm{~mm}$ syringe filter (Dynatech); an aliquot was frozen for later $\mathrm{NO}_{\mathrm{x}}^{-}$analysis (see 'Analysis' section). The headspace was replenished with Hesparged half-strength filtered seawater. After the incubation, porosity, density, and organic $\mathrm{C}$ and $\mathrm{N}$ measurements were made on the surface (0 to $2 \mathrm{~cm}$ ) sediment layer (see 'Analysis' section). Measured headspace gas concentrations were converted to masses using the measured headspace volume and pressure, and corrected for small losses due to gas withdrawals and fluxes out of the chambers. $D_{\mathrm{n}}$ was calculated from the difference between the slopes (least squares) of duplicate aerobic and anaerobic

Table 1. Fluxes (mmol m${ }^{-2} \mathrm{~d}^{-1}$ ) out of Mashapaquit Marsh sediments. Negative numbers indicate $\mathrm{O}_{2}$ consumption by sediments. All fluxes measured with $\mathrm{NO}_{\mathrm{x}}{ }^{-}$-free headspaces, except denitrification of water column nitrate $\left(D_{\mathrm{w}}\right)$, which was determined from added headspace $\mathrm{NO}_{\mathrm{x}}^{-}$uptake, as described in 'Materials and methods'. -: data not measured. S: sandy sediment; M: muddy sediment; $D_{\mathrm{n}}$ : coupled nitrification-denitrification

\begin{tabular}{|c|c|c|c|c|c|c|c|}
\hline Date (mm/dd/yy) & Site & $\mathrm{O}_{2}$ & $\mathrm{CO}_{2}$ & $D_{\mathrm{n}}$ & $\mathrm{NH}_{4}{ }^{+}$ & $\mathrm{NO}_{\mathrm{x}}^{-}$ & $D_{\mathrm{w}}$ \\
\hline 09/17/97 & $\begin{array}{c}\mathrm{S} \\
\mathrm{M}\end{array}$ & $\begin{array}{l}-64.3 \\
-80.8\end{array}$ & - & $\begin{array}{r}4.4 \\
11.4\end{array}$ & - & - & $\begin{array}{l}- \\
-\end{array}$ \\
\hline $06 / 25 / 98$ & $\begin{array}{c}\mathrm{S} \\
\mathrm{M}\end{array}$ & $\begin{array}{l}-74.3 \\
-54.6\end{array}$ & - & $\begin{array}{l}5.9 \\
4.4\end{array}$ & $\begin{array}{l}9.6 \\
8.8\end{array}$ & - & $\begin{array}{l}- \\
-\end{array}$ \\
\hline 08/11/98 & $\begin{array}{c}\mathrm{S} \\
\mathrm{M}\end{array}$ & $\begin{array}{r}-77.1 \\
-115.8\end{array}$ & - & $\begin{array}{r}6.1 \\
12.6\end{array}$ & $\begin{array}{l}13.5 \\
10.5\end{array}$ & $\begin{array}{l}- \\
-\end{array}$ & - \\
\hline $12 / 07 / 98$ & $\begin{array}{c}\mathrm{S} \\
\mathrm{M}\end{array}$ & $\begin{array}{l}-67.1 \\
-39.5\end{array}$ & - & $\begin{array}{l}6.3 \\
2.2\end{array}$ & - & $\begin{array}{l}0.1 \\
0.0\end{array}$ & $\begin{array}{l}1.0 \\
1.0\end{array}$ \\
\hline 03/16/99 & $\begin{array}{c}\mathrm{S} \\
\mathrm{M}\end{array}$ & $\begin{array}{l}-41.2 \\
-25.4\end{array}$ & $\begin{array}{l}32.5 \\
50.8\end{array}$ & $\begin{array}{l}6.2 \\
3.3\end{array}$ & - & - & $\begin{array}{l}1.6 \\
2.8\end{array}$ \\
\hline 05/12/99 & $\begin{array}{c}\mathrm{S} \\
\mathrm{M}\end{array}$ & $\begin{array}{l}-44.3 \\
-32.1\end{array}$ & $\begin{array}{l}51.3 \\
45.7\end{array}$ & $\begin{array}{l}4.4 \\
1.3\end{array}$ & - & $\begin{array}{l}- \\
-\end{array}$ & $\begin{array}{l}2.2 \\
2.4\end{array}$ \\
\hline 07/01/99 & $\begin{array}{c}\mathrm{S} \\
\mathrm{M}\end{array}$ & $\begin{array}{l}-48.8 \\
-61.4\end{array}$ & $\begin{array}{l}54.1 \\
55.5\end{array}$ & $\begin{array}{l}6.9 \\
4.0\end{array}$ & $\begin{array}{l}2.1 \\
5.4\end{array}$ & $\begin{array}{l}0.0 \\
0.0\end{array}$ & $\begin{array}{l}0.5 \\
1.6\end{array}$ \\
\hline 07/29/99 & $\begin{array}{c}\mathrm{S} \\
\mathrm{M}\end{array}$ & $\begin{array}{r}-59.5 \\
-102.7\end{array}$ & $\begin{array}{r}69.1 \\
105.7\end{array}$ & $\begin{array}{l}8.7 \\
9.0\end{array}$ & $\begin{array}{l}1.1 \\
7.6\end{array}$ & $\begin{array}{l}0.2 \\
0.0\end{array}$ & $\begin{array}{l}1.4 \\
2.5\end{array}$ \\
\hline $11 / 11 / 99$ & $\begin{array}{c}\mathrm{S} \\
\mathrm{M}\end{array}$ & $\begin{array}{l}-38.6 \\
-54.6\end{array}$ & $\begin{array}{l}19.5 \\
34.8\end{array}$ & $\begin{array}{l}3.7 \\
3.7\end{array}$ & - & $\begin{array}{l}0.0 \\
0.1\end{array}$ & $\begin{array}{l}1.7 \\
1.6\end{array}$ \\
\hline $01 / 10 / 00$ & $\begin{array}{c}\mathrm{S} \\
\mathrm{M}\end{array}$ & $\begin{array}{r}-9.9 \\
-13.9\end{array}$ & $\begin{array}{l}13.5 \\
14.6\end{array}$ & $\begin{array}{l}0.2 \\
1.3\end{array}$ & $\begin{array}{l}0.4 \\
1.2\end{array}$ & $\begin{array}{l}0.0 \\
0.0\end{array}$ & $\begin{array}{l}1.5 \\
1.8\end{array}$ \\
\hline $04 / 24 / 00$ & $\mathrm{~S}$ & -41.8 & 34.5 & 2.9 & 3.6 & - & - \\
\hline $06 / 22 / 00$ & $\begin{array}{c}\mathrm{S} \\
\mathrm{M}\end{array}$ & $\begin{array}{r}-68.5 \\
-103.8\end{array}$ & $\begin{array}{r}67.0 \\
103.5\end{array}$ & $\begin{array}{r}2.8 \\
10.1\end{array}$ & $\begin{array}{l}9.2 \\
5.7\end{array}$ & - & $\begin{array}{l}- \\
-\end{array}$ \\
\hline 08/03/00 & $\begin{array}{c}\mathrm{S} \\
\mathrm{M}\end{array}$ & $\begin{array}{l}-57.1 \\
-40.1\end{array}$ & $\begin{array}{l}54.5 \\
42.3\end{array}$ & $\begin{array}{l}6.1 \\
4.2\end{array}$ & $\begin{array}{l}4.8 \\
3.2\end{array}$ & - & $\begin{array}{l}- \\
-\end{array}$ \\
\hline 11/09/00 & $\mathrm{M}$ & -68.7 & - & 2.9 & 10.9 & - & - \\
\hline
\end{tabular}


$\mathrm{N}_{2}$ fluxes over time. $\mathrm{CO}_{2}, \mathrm{O}_{2}, \mathrm{NH}_{4}{ }^{+}$, and $\mathrm{NO}_{\mathrm{x}}{ }^{-}$fluxes were calculated from the slopes of their masses over time in duplicate aerobic chambers.

Denitrification of water column nitrate $\left(\boldsymbol{D}_{\mathrm{w}}\right) . D_{\mathrm{w}}$ was measured using 2 additional chambers incubated with added $\mathrm{KNO}_{3}$ on 7 dates. An initially high $\mathrm{NO}_{3}{ }^{-}$concentration $(500 \mu \mathrm{M})$ was chosen to enable the study of non-substrate-limited $D_{\mathrm{w}}$ kinetics. $\mathrm{NO}_{\mathrm{x}}{ }^{-}$and $\mathrm{N}_{2}$ measurements were made daily until $\mathrm{NO}_{3}{ }^{-}$concentrations fell to $<10 \mu \mathrm{M}$. $D_{\mathrm{w}}$-derived $\mathrm{N}_{2}$ production was calculated by subtracting the $\mathrm{N}_{2}$ flux in nitrate-free aerobic microcosms from the $\mathrm{N}_{2}$ flux in $\mathrm{NO}_{3}{ }^{-}$-enriched aerobic microcosms. Since the salt marsh creek undergoes tidal $\mathrm{NO}_{3}{ }^{-}$variation, the substrate-limited response of $D_{\mathrm{w}}$ was determined from in situ bottom-water $\mathrm{NO}_{3}{ }^{-}$ concentrations. The average daily bottom-water $\mathrm{NO}_{\mathrm{x}}{ }^{-}$ concentration at each site was measured just above the sediment surface every $2 \mathrm{~h}$ over a complete tidal cycle in January (lowest sediment metabolism) and again in August (maximum sediment metabolism). Nitrate uptake rather than $D_{\mathrm{w}}$-derived $\mathrm{N}_{2}$ production was used as a measure of $D_{\mathrm{w}}$, since we were unable to generate substrate limitation curves using $D_{\mathrm{w}}$-derived $\mathrm{N}_{2}$ production because of $\mathrm{N}_{2}$ production lags and the cumulative errors associated with this method.

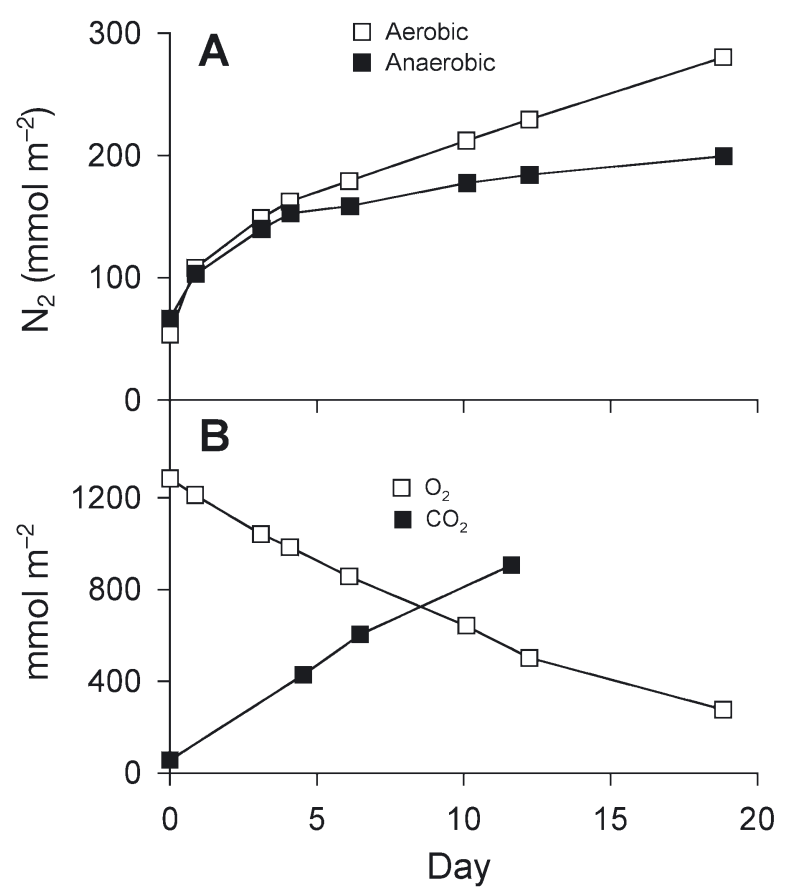

Fig. 2. (A) Example of $\mathrm{N}_{2}$ gas efflux from salt marsh tidal creek sediment cores to $\mathrm{N}_{2}$-free gas headspace in an aerobic and anaerobic microcosm. Denitrification flux derived from difference between aerobic (denitrification + diffusion) and anaerobic (diffusion only) $\mathrm{N}_{2}$ fluxes. (B) $\mathrm{O}_{2}$ consumption and total $\mathrm{CO}_{2}$ production in aerobic sediment microcosm measured simultaneously with $\mathrm{N}_{2}$ flux. $\mathrm{CO}_{2}$ measurements were made only 4 times
Analysis. Gas samples were analyzed on a Shimadzu GC-14A gas chromatograph fitted with a thermal conductivity detector and calibrated with a certified gas mixture (Scott Specialty Gasses). Samples were injected off-column to avoid uncertainties resulting from gas volume, temperature, and pressure variations. Dissolved $\mathrm{NH}_{4}{ }^{+}$was analyzed immediately (to prevent volatilization) by a colorimetric indophenol method (Scheiner 1976). $\mathrm{NO}_{\mathrm{x}}^{-}$was analyzed with azo dye after cadmium reduction on a Lachat ${ }^{\mathrm{TM}}$ automated ion analyzer (Wood et al. 1967). Dissolved $\mathrm{CO}_{2}$ was determined by acidification and headspace equilibration, followed by infrared analysis (Beckman 15A). Salinity was measured with a YSI conductivity meter. Known volumes of sediment were weighed wet and dried to constant weight $\left(60^{\circ} \mathrm{C}\right)$ to determine porosity and density. Dried and ground sediments were analyzed for organic C and N (Perkin-Elmer 2400). Sediment carbonate content analysis (by acidification) showed that carbonate accounted for $<0.01 \%$ of total sediment C. Frozen sediments were extracted with chilled $1 \mathrm{mg} \mathrm{MgCO}_{3} \mathrm{l}^{-1}$ acetone, and analyzed for chl a and pheophytin by fluorometry (Turner ${ }^{\mathrm{TM}}$ 10-AU). Isotopic composition $\left({ }^{13} \mathrm{C}\right.$ and $\left.{ }^{15} \mathrm{~N}\right)$ of sediments and macroalgal biomass was determined by mass spectrometry (Carlo Erba T1500, Stable Isotope Facility, University of California, Davis). Correlation coefficients (r) were calculated by the Pearson productmoment method. Slopes were calculated by the least squares method. Means are reported $\pm \mathrm{SE}$.

\section{RESULTS}

\section{Sediment metabolic rates}

$\mathrm{N}_{2}$ concentrations in the headspace of both anaerobic (He headspace) and aerobic ( $\mathrm{He}_{2} \mathrm{O}_{2}$ headspace) salt-marsh creek sediment-microcosms initially rose rapidly (Fig. 2A). Upon chamber closure, sediment $\mathrm{N}_{2}$ pools were in near-equilibrium with atmospheric $\mathrm{N}_{2}$ levels, while the chamber headspace was $\mathrm{N}_{2}$ depleted. This initial concentration gradient of $\mathrm{N}_{2}$ across the sediment-water interface drove high diffusion rates. As sediment $\mathrm{N}_{2}$ pools were depleted, diffusion slowed, and after $3 \mathrm{~d}$ sediment $\mathrm{N}_{2}$ flux was nearly linear. In both anaerobic and aerobic microcosms, residual diffusion of porewater $\mathrm{N}_{2}$ and diffusion of atmospheric $\mathrm{N}_{2}$ continued to contribute to the flux after Day 3. With nitrification anaerobically inhibited and no headspace $\mathrm{NO}_{\bar{x}}^{-}$, there was no denitrification in anaerobic microcosms. In contrast, in aerobic cores (He: $\mathrm{O}_{2}$ headspace), denitrification of $\mathrm{NO}_{3}{ }^{-}$produced in situ through nitrification caused aerobic $\mathrm{N}_{2}$ fluxes to exceed anaerobic fluxes. In all experiments, ammonium fluxes from the 
sediments were positive, while $\mathrm{NO}_{\mathrm{x}}^{-}$fluxes (in $\mathrm{NO}_{\mathrm{x}}{ }^{-}-$ free incubations) were inconsiderable, at $<2 \%$ of $\mathrm{N}$ mineralization rates (Table 1). Headspace $\mathrm{O}_{2}$ was consumed in the sediments by aerobic heterotrophy and the oxidation of reduced metabolic products (primarily $\mathrm{S}^{2-}$ and $\mathrm{NH}_{4}^{+}$) (Fig. 2B). Although $\mathrm{O}_{2}$ consumption was constant at $\mathrm{O}_{2}$ concentrations $>10 \%$ atm, $\mathrm{O}_{2}$ consumption and other metabolic rates were determined only while $\mathrm{O}_{2}$ concentrations were $>30 \%$ atm (Nowicki 1994). Headspace $\mathrm{CO}_{2}$ concentrations ( 80\% as dissolved $\mathrm{CO}_{2}$ ) increased because of the heterotrophic degradation of organic matter.

$\mathrm{O}_{2}$ consumption, $\mathrm{CO}_{2}$ production, and $D_{\mathrm{n}}$ within the salt marsh creek sediments varied seasonally, with lows in the winter and highs in late summer (Fig. 3, Table 1). There was a 10-fold variation in $\mathrm{O}_{2}$ consumption rates (sandy sediments range: 9.9 to $106 \mathrm{mmol} \mathrm{m}^{-2}$ $\mathrm{d}^{-1}$; muddy sediments: 13.9 to $116 \mathrm{mmol} \mathrm{m}^{-2} \mathrm{~d}^{-1}$ ), $\mathrm{CO}_{2}$ consumption varied $>5$-fold (sandy sediments range: 13.5 to $69.1 \mathrm{mmol} \mathrm{m}^{-2} \mathrm{~d}^{-1}$; muddy sediments: 14.6 to $106 \mathrm{mmol} \mathrm{m}^{-2} \mathrm{~d}^{-1}$ ), and the range of $D_{\mathrm{n}}$ was larger in sandy sediments, at 0.2 to $8.7 \mathrm{mmol} \mathrm{N} \mathrm{m}^{-2} \mathrm{~d}^{-1}$, and 1.3 to $12.6 \mathrm{mmol} \mathrm{N} \mathrm{m}^{-2} \mathrm{~d}^{-1}$ in muddy sediments. Betweenyear variation was lower than within-year variation.
$\mathrm{O}_{2}, \mathrm{CO}_{2}$, and $D_{\mathrm{n}}$ fluxes were all significantly correlated with temperature (Fig. 4), though the degree of correlation with $D_{\mathrm{n}}$ was low.

\section{Sediment metabolism and organic carbon quality}

Sandy and muddy sediments were differentiated based on density, which was bimodally distributed. Sandy and muddy sediments differed in porosity, density, and organic content (Table $2 ; \mathrm{p}<0.001$ ). Sandy sediments were coarse grained, with dry densities averaging $1.22 \pm 0.05 \mathrm{~g} \mathrm{~cm}^{-3}$, while muddy sediments were fine grained and only $1 / 3$ as dense as sandy sediments $\left(0.39 \pm 0.04 \mathrm{~g} \mathrm{~cm}^{-3}\right)$. Surficial sediment organic $\mathrm{C}(0$ to $2 \mathrm{~cm})$ at the sandy site averaged $0.55 \pm$ $0.05 \mathrm{mmol} \mathrm{cm}^{-3}$, less than $1 / 2$ the organic $C$ content of

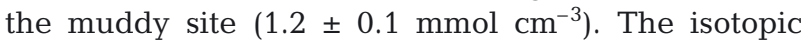
composition of sediment $\mathrm{C}$ at both sites $\left(\delta^{13} \mathrm{C}=-20.8 \pm\right.$ $0.8 \%$ [sandy] and $-18.5 \pm 0.2 \%$ [muddy]) was depleted in ${ }^{13} \mathrm{C}$ relative to aboveground vegetation of Spartina alterniflora $(-12.6 \pm 0.1 \%)$, marsh peat $(-15.0 \pm 0.3 \%)$, or the dominant benthic macroalga Enteromorpha intestinata $(-17.0 \pm 0.4 \%)$. Total photosynthetic pig-
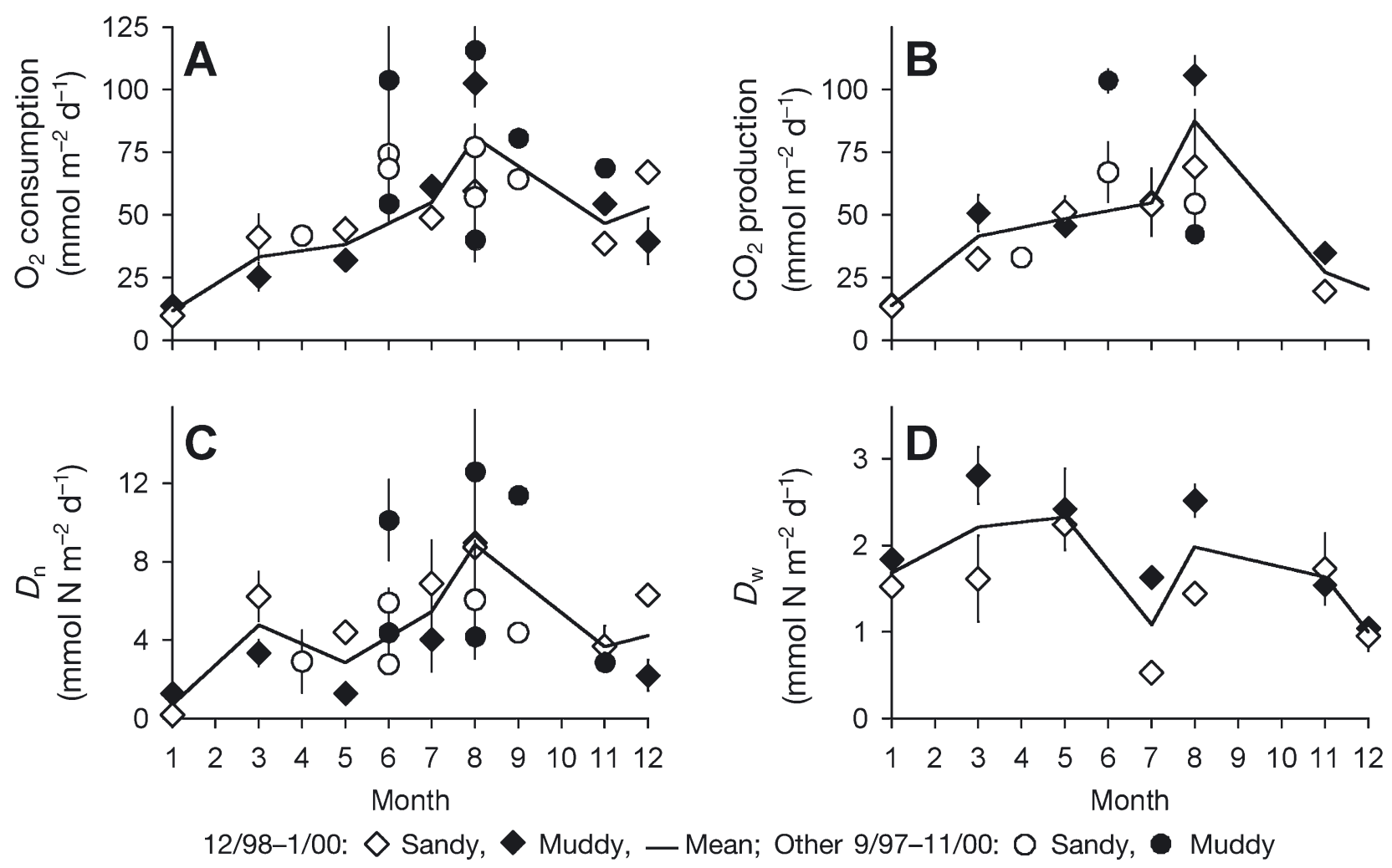

Fig. 3. Seasonal cycles of sediment fluxes measured over 4 annual cycles from 1997 to 2001 in sandy and muddy salt marsh tidal creek sediments. Bimonthly measurements were made in 1999 (diamonds, December 1998 to January 2000; average flux across both sites is indicated by the solid line), with less frequent measurements (concentrated during the summer) made during other years (circles, September 1997 to November 2000). Points are means $\left( \pm\right.$ SE) of paired microcosms. (A) Sediment $\mathrm{O}_{2}$ consumption.

(B) Sediment total $\mathrm{CO}_{2}$. (C) Coupled nitrification-denitrification $\left(D_{\mathrm{n}}\right)$. (D) Denitrification of water column $\mathrm{NO}_{3}^{-}\left(D_{\mathrm{w}}\right)$ 
ment content (chl $a+$ pheophytin) in sandy sediments $\left(1010 \pm 330 \mu \mathrm{g} \mathrm{cm}^{-3}\right)$ was twice that of muddy sediments $\left(590 \pm 100 \mathrm{\mu g} \mathrm{cm}^{-3}\right)$. The contribution of labile benthic-algal biomass to sediment organic $\mathrm{C}$ was estimated by normalizing pigment content to sediment organic C. Labile benthic-algal biomass made a greater contribution to sandy sediment C $(8.8 \pm 3.1 \mu \mathrm{g}$ pigment $\left.\mathrm{mg} \mathrm{C}^{-1}\right)$ than to muddy sediment $\mathrm{C}(1.8 \pm$ $0.7 \mu \mathrm{g}$ pigment $\mathrm{mg} \mathrm{C}^{-1}$ ).

Although significant differences in sediment composition were found, mean metabolic rates did not significantly differ between the 2 sediment types. The mean $\mathrm{O}_{2}$ consumption of sandy sediments $\left(58 \pm 6 \mathrm{mmol} \mathrm{O}_{2}\right.$ $\mathrm{m}^{-2} \mathrm{~d}^{-1}$ ) was the same as that of muddy sediments $\left(62 \pm 9 \mathrm{mmol} \mathrm{m}^{-2} \mathrm{~d}^{-1}\right)(\mathrm{p}=0.30)$. Likewise, no significant differences were found in $\mathrm{CO}_{2}$ production $(46 \pm 7$ vs $\left.58 \pm 10 \mathrm{mmol} \mathrm{m}^{-2} \mathrm{~d}^{-1} ; \mathrm{p}=0.07\right)$ or $D_{\mathrm{n}}(4.9 \pm 0.6$ vs $\left.5.4 \pm 1.1 \mathrm{mmol} \mathrm{N} \mathrm{m}^{-2} \mathrm{~d}^{-1} ; \mathrm{p}=0.36\right)$. However, sandy

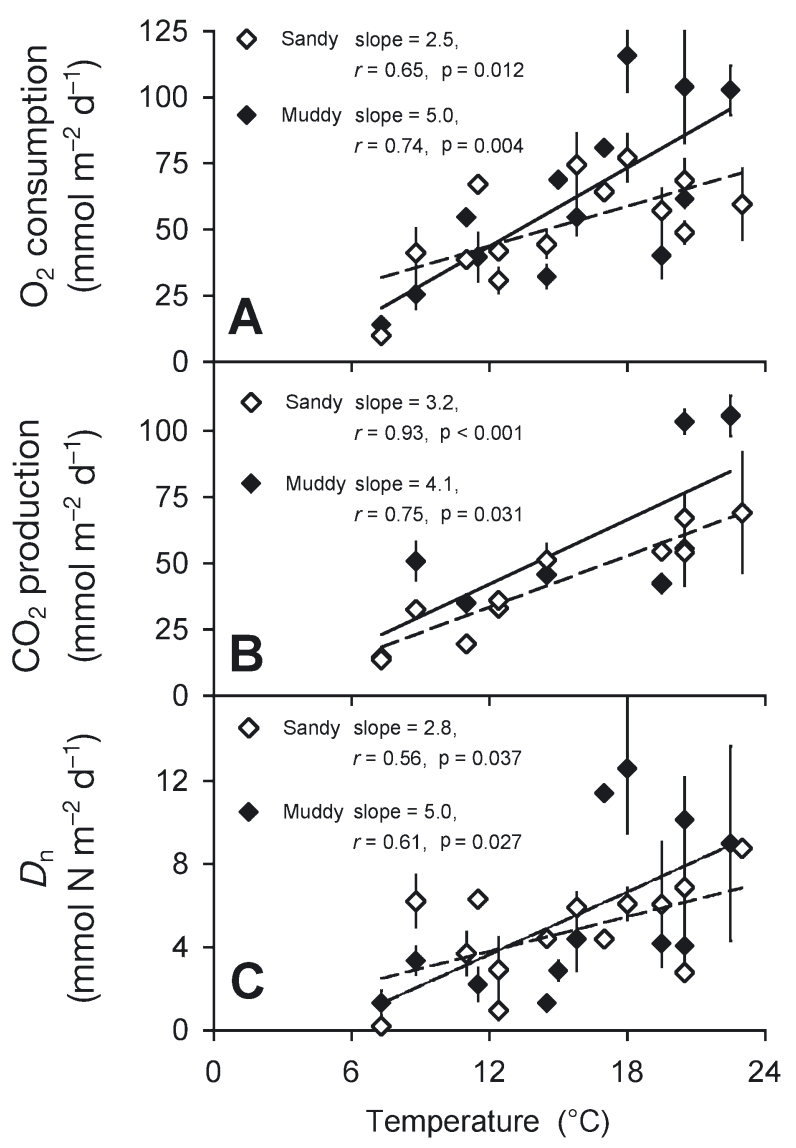

Fig. 4. Relationship between field temperature and sediment metabolic rates. Data are from seasonally sampled sediment cores incubated at in situ field temperatures, rather than temperature manipulations. Points are means $( \pm \mathrm{SE})$ of paired microcosms. (A) $\mathrm{O}_{2}$ consumption. (B) $\mathrm{CO}_{2}$ production. (C) Coupled nitrification-denitrification $\left(D_{\mathrm{n}}\right)$. Lines are linear regressions; the slope, correlation coefficient (r), and significance (p) are shown sediment organic $\mathrm{C}$ was twice as reactive as muddy sediment organic $\mathrm{C}$ (sediment $\mathrm{C}$ turnover: sandy, $1.5 \pm 0.3 \mathrm{yr}^{-1}$; muddy, $\left.0.9 \pm 0.2 \mathrm{yr}^{-1}\right)$.

Metabolic rates were highly correlated with amount of sediment $\mathrm{C}$ in each sediment type (Fig. 5). Sediment $\mathrm{O}_{2}$ demand was positively correlated with sediment $\mathrm{C}$ in both sandy and muddy sediments, but muddy sediments were less metabolically active than sandy sediments, requiring a higher sediment $\mathrm{C}$ concentration to achieve the same sediment $\mathrm{O}_{2}$ uptake rate. The same pattern was repeated for $\mathrm{CO}_{2}$ production, $D_{\mathrm{n}}$, and non-substrate-limited sediment $\mathrm{NO}_{3}^{-}$ uptake. Temperature and sediment $\mathrm{C}$ were significantly correlated only in sandy sediments $(\mathrm{r}=0.57$; $\mathrm{p}$ $=0.03$ ). Both temperature and sediment $\mathrm{C}$ were significantly correlated with all metabolic rates $(\mathrm{r}=0.56$ to 0.93 ; $\mathrm{p}<0.04$ ) (Figs. $4 \& 5$ ). However, $D_{\mathrm{n}}$ was more strongly correlated with sediment $C$ than with temperature.

\section{Denitrification of water column nitrate $\left(D_{\mathrm{w}}\right)$}

Since $\mathrm{NO}_{3}{ }^{-}$concentrations in the salt marsh creek varied with the semi-diurnal tides, average daily in situ $D_{\text {w }}$ was calculated using the empirical relationship between $D_{\mathrm{w}}$ and $\mathrm{NO}_{3}{ }^{-}$concentration determined during the course of each sediment incubation. However, we were unable to construct such a relationship using $D_{\mathrm{w}}$-derived $\mathrm{N}_{2}$ production, and so determined $D_{\mathrm{w}}$ from the $\mathrm{NO}_{\mathrm{x}}{ }^{-}$uptake. A number of lines of evidence led us to believe that $\mathrm{NO}_{\mathrm{x}}{ }^{-}$uptake was due to $D_{\mathrm{w}}$ alone. First, in $\mathrm{NO}_{3}{ }^{-}$containing aerobic microcosms, headspace $\mathrm{NO}_{\mathrm{x}}{ }^{-}$declined concurrently with $D_{\mathrm{w}}$-derived $\mathrm{N}_{2}$ accumulation (Fig. 6A). A significant contribution of dissimilatory $\mathrm{NO}_{3}{ }^{-}$reduction to $\mathrm{NH}_{4}{ }^{+}$(DNRA) was ruled out because $D_{\mathrm{w}}$-derived $\mathrm{N}_{2}$ production in the incubations did not significantly differ from $\mathrm{NO}_{3}{ }^{-}$uptake (Fig. $6 \mathrm{~B}$; $\mathrm{r}=0.74 ;$ paired $t$-test $; \mathrm{p}=0.21$ ). Further, $\mathrm{NH}_{4}{ }^{+}$fluxes in $\mathrm{NO}_{3}{ }^{-}$-amended microcosms did not differ from those in $\mathrm{NO}_{3}{ }^{-}$-free microcosms $(\mathrm{r}=0.80$; paired $t$-test; $\mathrm{p}=0.90)$, indicating no increased $\mathrm{NH}_{4}{ }^{+}$production in the presence of $\mathrm{NO}_{3}{ }^{-}$. Likewise, algal $\mathrm{NO}_{\mathrm{x}}{ }^{-}$uptake was likely inhibited during the long ( $>3$ d) dark incubations. Although substrate limitation of $\mathrm{NO}_{\mathrm{x}}{ }^{-}$uptake could be modeled with Michaelis-Menten kinetics (Fig. 6A, inset), uptake was linear within the range of field $\mathrm{NO}_{\mathrm{x}}^{-}$ levels $(<100 \mu \mathrm{M})$, and first-order $\mathrm{NO}_{\mathrm{x}}{ }^{-}$uptake coefficients were used to calculate $D_{\mathrm{w}}$ from mean bottomwater $\mathrm{NO}_{\mathrm{x}}^{-}$concentrations (Table 2). $D_{\mathrm{w}}$ ranged from 0.5 to $2.2 \mathrm{mmol} \mathrm{N} \mathrm{m} \mathrm{m}^{-2} \mathrm{~d}^{-1}$ in sandy sediments, and from 1.0 to $2.8 \mathrm{mmol} \mathrm{N} \mathrm{m}^{-2} \mathrm{~d}^{-1}$ in muddy sediments, with no seasonal trend observed (Fig. 3D). Nevertheless, the contribution of $D_{\mathrm{w}}$ to total denitrification peaked in January $(69 \%)$ and reached its lowest point in July 
Table 2. Characteristics of sandy (S) and muddy (M) Mashapaquit Marsh sites (see Fig. 1). p-values are the result of 2 sample $t$-tests (2-tailed) comparing the 2 sites

\begin{tabular}{|c|c|c|c|c|c|c|c|}
\hline & \multicolumn{3}{|c|}{ Sandy } & \multicolumn{3}{|c|}{ Muddy } & \multirow{2}{*}{$\begin{array}{c}\text { Significance } \\
(\mathrm{p})\end{array}$} \\
\hline & Mean & $\mathrm{SE}$ & $\mathrm{n}$ & Mean & $\mathrm{SE}$ & $\mathrm{n}$ & \\
\hline \multicolumn{8}{|l|}{ Proportion of tidal creek area } \\
\hline \multicolumn{8}{|l|}{ Sediment characteristics (top $2 \mathrm{~cm}$ ) } \\
\hline Density $\left(\mathrm{g} \mathrm{cm}^{-3}\right)$ & 1.22 & $(0.05)$ & 28 & 0.39 & $(0.04)$ & 24 & $<0.001$ \\
\hline Porosity $\left(\mathrm{ml} \mathrm{cm}^{-3}\right)$ & 53 & (2) & 28 & 81 & (2) & 24 & $<0.001$ \\
\hline Organic carbon $\left(\mathrm{mmol} \mathrm{cm}{ }^{-3}\right)$ & 0.55 & $(0.05)$ & 27 & 1.2 & $(0.1)$ & 24 & $<0.001$ \\
\hline Organic nitrogen $\left(\mathrm{mmol} \mathrm{cm}{ }^{-3}\right)$ & 0.052 & $(0.009)$ & 28 & 0.113 & $(0.013)$ & 24 & $<0.001$ \\
\hline $\mathrm{C}: \mathrm{N}$ molar ratio & 10.3 & $(0.3)$ & 24 & 10.7 & $(0.2)$ & 24 & 0.09 \\
\hline$\delta^{13} \mathrm{C}(\%)$ & -20.8 & $(0.8)$ & 6 & -18.5 & $(0.2)$ & 6 & 0.01 \\
\hline${ }^{15} \mathrm{~N}\left(\mathrm{~atm} \%{ }^{15} \mathrm{~N}\right)$ & 0.3692 & $(0.0003)$ & 6 & 0.3686 & $(0.0003)$ & 6 & 0.08 \\
\hline Total pigment $\left(\mu \mathrm{g} \mathrm{cm}^{-3}\right)^{\mathrm{a}}$ & 1010 & $(330)$ & 4 & 590 & $(100)$ & 4 & 0.04 \\
\hline Pigment/sediment C $\left(\mu \mathrm{g} \mathrm{mg}^{-1}\right)$ & 8.8 & $(3.1)$ & 4 & 1.8 & $(0.7)$ & 4 & 0.01 \\
\hline $\mathrm{O}_{2}$ consumption $\left(\mathrm{mmol} \mathrm{O} \mathrm{O}^{-2} \mathrm{~d}^{-1}\right.$ ) & 58 & $(6)$ & 13 & 62 & (9) & 13 & 0.30 \\
\hline 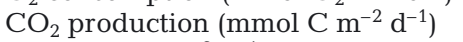 & 46 & $(7)$ & 8 & 58 & (10) & 8 & 0.07 \\
\hline$D_{\mathrm{n}}\left(\mathrm{mmol} \mathrm{N} \mathrm{m}^{-2} \mathrm{~d}^{-1}\right)$ & 4.9 & $(0.6)$ & 13 & 5.4 & $(1.1)$ & 13 & 0.36 \\
\hline$D_{\mathrm{w}}\left(\mathrm{mmol} \mathrm{N} \mathrm{m}^{-2} \mathrm{~d}^{-1}\right)$ & 1.4 & $(0.2)$ & 7 & 2.0 & $(0.2)$ & 7 & 0.044 \\
\hline Sediment organic $\mathrm{C}$ turnover $\left(\mathrm{yr}^{-1}\right)$ & 1.5 & $(0.3)$ & 12 & 0.9 & $(0.2)$ & 12 & $<0.001$ \\
\hline Bottom-water $\mathrm{NO}_{\mathrm{x}}^{-}(\mu \mathrm{M})^{\mathrm{b}}$ & 27 & $(0.4-95.6)$ & 16 & 29 & $(0.9-133.4)$ & 16 & \\
\hline
\end{tabular}
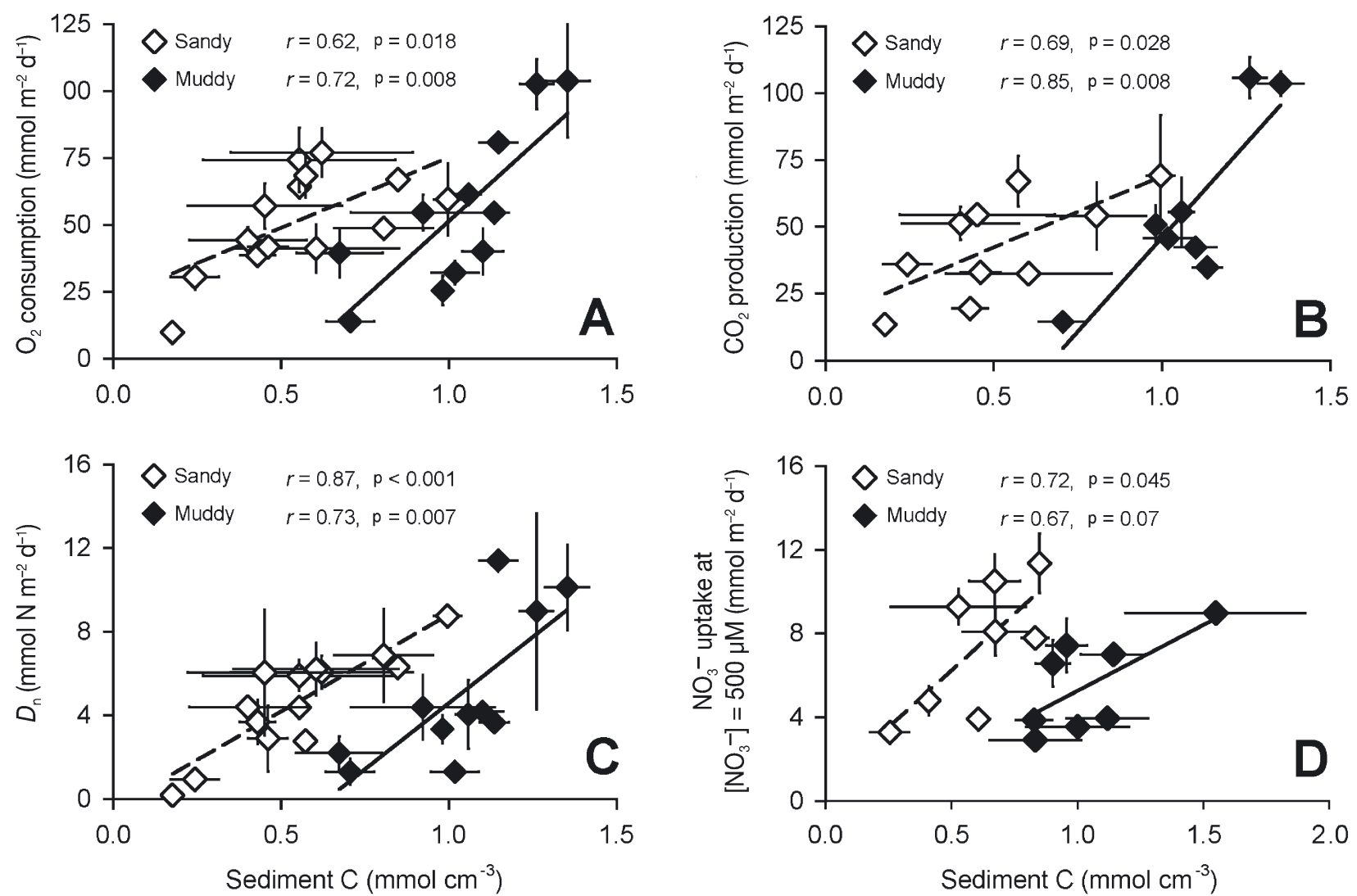

Fig. 5. Relationship between sediment organic-C content and metabolic rates. Data are from seasonal sampling, and variations in $\mathrm{C}$ content within the sediment types are due to spatial and temporal heterogeneity within a single sampling site. (A) $\mathrm{O}_{2}$ consumption. (B) $\mathrm{CO}_{2}$ production. (C) Coupled nitrification-denitrification ( $D_{\mathrm{n}}$ ). (D) $\mathrm{NO}_{3}{ }^{-}$uptake at non-limiting $\mathrm{NO}_{3}{ }^{-}$concentration $(500 \mu \mathrm{M})$. Points are means $( \pm \mathrm{SE})$ of paired microcosms. The correlation coefficient $(\mathrm{r})$ and its significance $(\mathrm{p})$ are shown 

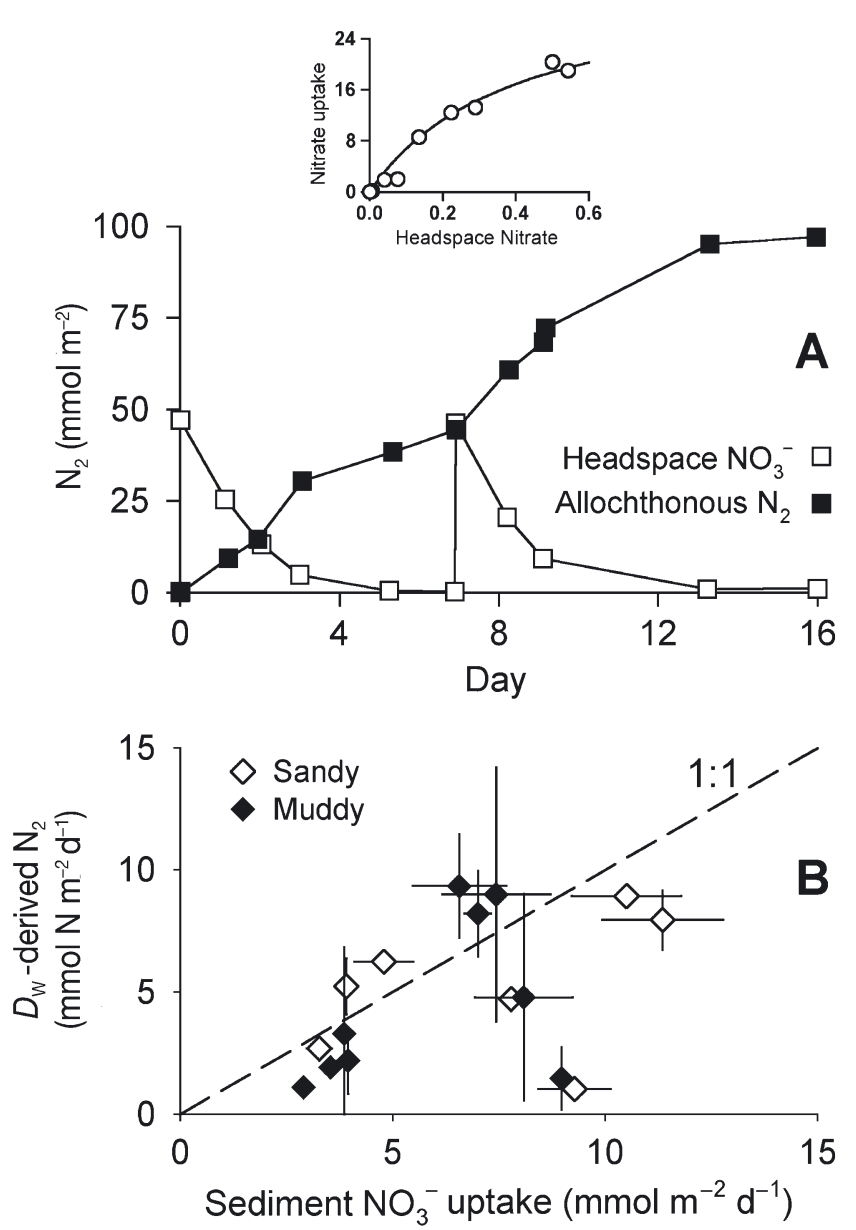

Fig. 6. (A) Example of water column $\mathrm{NO}_{\mathrm{x}}{ }^{-}$-driven denitrification in an aerobic salt marsh creek sediment microcosm (5 December 1999). Open squares show course of $\mathrm{NO}_{\mathrm{x}}{ }^{-}$ losses after $\mathrm{NO}_{3}{ }^{-}$additions at 0 and $7 \mathrm{~d}$. Closed squares show concomitant evolution of $\mathrm{N}_{2}$ from denitrification of water column $\mathrm{NO}_{3}{ }^{-}$. Inset shows kinetics of $\mathrm{NO}_{3}{ }^{-}$uptake $\left(\mathrm{mmol} \mathrm{m}^{-2} \mathrm{~d}^{-1}\right)$ with $\mathrm{NO}_{3}{ }^{-}$concentration (mM) for both $\mathrm{NO}_{3}{ }^{-}$additions. Curve is nonlinear fit of Michaelis-Menten equation. (B) Relationship of denitrification of water column nitrate $\left(D_{\mathrm{w}}\right)$-driven $\mathrm{N}_{2}$ production to water column $\mathrm{NO}_{3}{ }^{-}$uptake for all incubations. Points are means of paired cores $( \pm \mathrm{SE})$. Dashed line represents 1:1 ratio

$(17 \%)$ due to the seasonality of $D_{\mathrm{n}}$. The annual total denitrification flux $\left(2.3 \mathrm{~mol} \mathrm{~N} \mathrm{~m}^{-2} \mathrm{yr}^{-1}\right)$ from these tidal salt marsh sediments was dominated by $D_{\mathrm{n}}(1.6 \mathrm{~mol} \mathrm{~N}$ $\mathrm{m}^{-2} \mathrm{yr}^{-1}$, or $\left.72 \%\right)$, with the remainder $\left(0.66 \mathrm{~mol} \mathrm{~N} \mathrm{~m}^{-2}\right.$ $\mathrm{yr}^{-1}$, or $28 \%$ ) accounted for by $D_{\mathrm{w}}$.

\section{Elemental sediment-flux ratios}

The molar ratios of $\mathrm{CO}_{2}, \mathrm{O}_{2}$, and $\mathrm{N}$ fluxes across the sediment-water interface were relatively constant between seasons for both sediment types (Fig. 7). Correlation coefficients ranged from $r=0.94$ for the
$\mathrm{O}_{2}: \mathrm{CO}_{2}$ flux ratio, to $\mathrm{r}=0.97$ for the $\mathrm{C}: \mathrm{N}$ flux ratio. The C:N flux ratio averaged 6.1 (Fig. 7A), similar to the Redfield ratio for algal biomass $(6.6$; Redfield 1934). In contrast, the particulate $C: N$ ratios of the available bulk organic matter sources were higher. The C:N ratio of sediment organic material ranged from 7.5 to 14.7 , while suspended particulate matter in the surface waters of the salt marsh creek ranged from 5.9 to 10.4 (Smith 1999). C:N ratios of the dominant benthic macroalga Enteromorpha intestinata averaged $8.6 \pm 0.3 ; \mathrm{C}: \mathrm{N}$ ratios of vegetated marsh peat averaged $24.7 \pm 0.8$, and C:N ratios of Spartina alterniflora leaves and stems averaged $41.8 \pm 2.6$. The molar flux ratio of $\mathrm{O}_{2}: \mathrm{CO}_{2}$ averaged 1.0 at Sites $\mathrm{S}$ and $\mathrm{M}$ (Fig. $7 \mathrm{~B}$ ), while the $\mathrm{O}_{2}: \mathrm{N}$ flux ratio averaged 5.6 (Fig. 7C).

\section{Contribution of nitrification-denitrification to sediment metabolism}

Nitrification and denitrification represented a relatively constant proportion of total sediment metabolism $\left(\mathrm{O}_{2}, \mathrm{CO}_{2}\right.$, and $\left.\mathrm{N}\right)$ over the entire range of metabolic rates and sediment types (Fig. 8). $\mathrm{O}_{2}$ consumption by nitrification accounted for an average of $18 \%$ (range 6 to $30 \%$ ) of the total sediment $\mathrm{O}_{2}$ consumption (Fig. 8A). The net sediment $\mathrm{CO}_{2}$ flux resulting from coupled nitrification-denitrification reactions averaged $10 \%$ ( 2 to $22 \%$ ), and was predominately a result of heterotrophic $\mathrm{CO}_{2}$ production by $D_{\mathrm{n}}$, while chemoautotrophic $\mathrm{CO}_{2}$ consumption by nitrifiers amounted to $1 / 10 D_{\mathrm{n}}$ production (Fig. 8B). $D_{\mathrm{w}}$ contributed a further $5 \%$, for a total annual contribution of nitrification-denitrification to total $\mathrm{CO}_{2}$ flux of $15 \%$. The role of coupled nitrification-denitrification in the sedimentary $\mathrm{N}$ cycle was larger, accounting for $46 \%$ (21 to $89 \%$ ) of the total $\mathrm{NH}_{4}{ }^{+}$regeneration in the sediments (Fig. $8 \mathrm{C}$ ).

\section{DISCUSSION}

Nitrification and denitrification were significant contributors to the cycling of $\mathrm{N}, \mathrm{C}$, and $\mathrm{O}_{2}$ in both sandy and muddy Mashapaquit Marsh tidal creek sediments, converting $46 \%$ of remineralized $\mathrm{N}$ into $\mathrm{N}_{2}$ gas and contributing an average of $15 \%$ to the $\mathrm{CO}_{2}$ flux and $18 \%$ to the total $\mathrm{O}_{2}$ consumption. $D_{\mathrm{n}}$ in the salt marsh sediments was controlled primarily by sediment organic-C lability and concentration, and secondarily by seasonal effects such as temperature. Sediment metabolism was driven by degradation of algal organic matter for which groundwater $\mathrm{NO}_{3}{ }^{-}$was the primary source. Therefore, although $D_{\mathrm{w}}$ accounted for only $28 \%$ of the total annual denitrification, the 

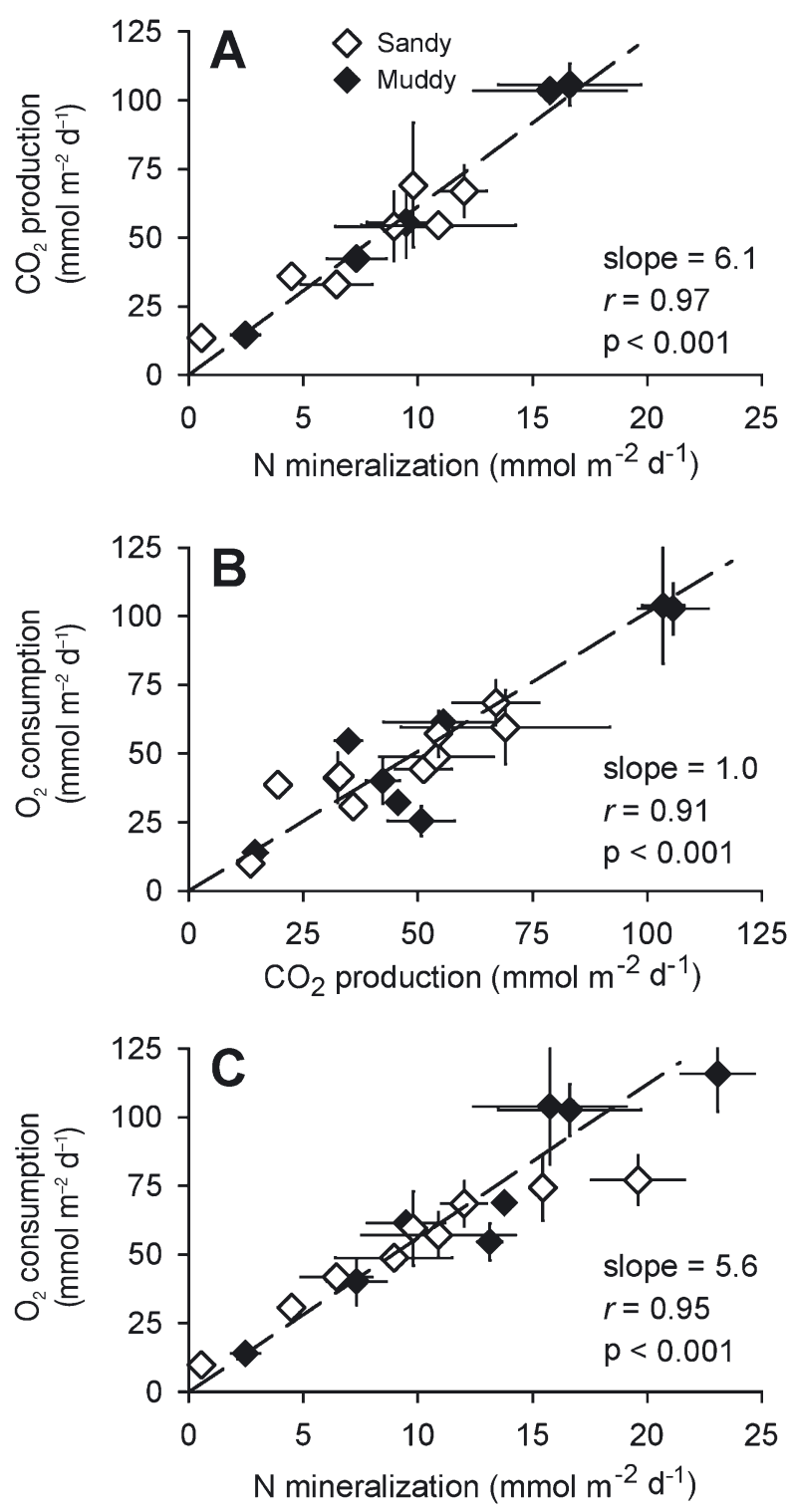

Fig. 7. Elemental ratios of $\mathrm{CO}_{2}, \mathrm{~N}$, and $\mathrm{O}_{2}$ fluxes across the sediment-water interface in salt marsh tidal creek sediment microcosms. $\mathrm{CO}_{2}$ production is dissolved inorganic $\mathrm{C}+$ gas; $\mathrm{N}$ mineralization is the sum of $\mathrm{NH}_{4}{ }^{+}, \mathrm{NO}_{\mathrm{x}}{ }^{-}$and $\mathrm{N}_{2}$ fluxes. (A) $\mathrm{CO}_{2}: \mathrm{N}$. (B) $\mathrm{O}_{2}: \mathrm{CO}_{2}$. (C) $\mathrm{O}_{2}: \mathrm{N}$. Points are means of paired cores $( \pm \mathrm{SE})$. Lines are least-squares lines (constant $=0$ ) through all points. Slope, correlation coefficient (r), and significance (p) are shown

remaining $\mathrm{N}$ loss through coupled nitrification-denitrification also represented a denitrification sink for groundwater $\mathrm{NO}_{3}$.

\section{Elemental sediment-flux ratios}

Sediment $\mathrm{O}_{2}$ consumption can be described as the sum of 3 terms: aerobic organic-C oxidation, oxidation
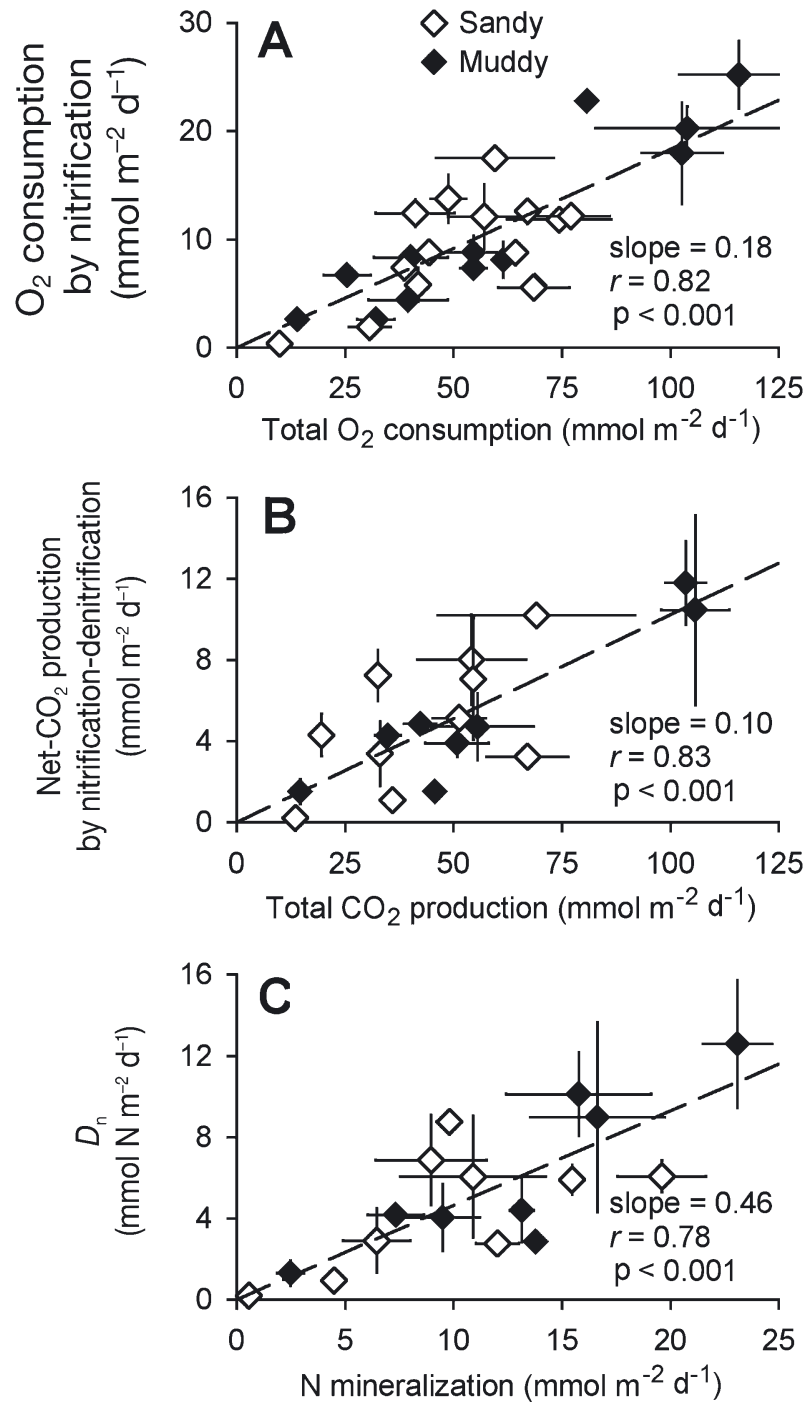

Fig. 8. Elemental fluxes resulting from coupled nitrificationdenitrification $\left(D_{\mathrm{n}}\right)$ in salt marsh tidal creek sediments (determined stoichiometrically from $\mathrm{N}_{2}$ flux). Slope of least-squares fits indicates the average proportion of the elemental flux due to nitrification-denitrification. (A) $\mathrm{O}_{2}$ consumption of nitrification in relation to overall sediment $\mathrm{O}_{2}$ consumption. (B) $\mathrm{CO}_{2}$ production resulting from coupled nitrification-denitrification (autotrophic $\mathrm{CO}_{2}$ consumption of nitrification + heterotrophic $\mathrm{CO}_{2}$ production from denitrification) in relation to total $\mathrm{CO}_{2}$ production. (C) $D_{\mathrm{n}}$-derived $\mathrm{N}$ flux in relation to total $\mathrm{N}$ mineralization $\left(\mathrm{NH}_{4}{ }^{+}+\mathrm{NO}_{3}{ }^{-}+\mathrm{N}_{2}\right)$. The correlation coefficient (r) and its significance (p) are shown. Points are means of paired cores $( \pm \mathrm{SE})$

of the non-nitrogenous reduced end-products of anaerobic metabolism (primarily $\mathrm{S}^{2-}$ ), and autotrophic oxidation of mineralized $\mathrm{NH}_{4}{ }^{+}$:

$$
O_{\mathrm{T}}=C_{\mathrm{Ox}} P_{\mathrm{Ox}}+C_{\mathrm{An}} P_{\mathrm{An}}+2 N_{\mathrm{T}} P_{\mathrm{N}}
$$

where $O_{\mathrm{T}}=$ total sediment $\mathrm{O}_{2}$ consumption rate, $C_{\mathrm{Ox}}=$ aerobic $\mathrm{C}$ metabolism rate, $P_{\mathrm{Ox}}=$ proportion of non- 
nitrogenous end products of aerobic metabolism oxidized $\left(P_{\mathrm{Ox}}=1\right.$; Redfield 1934), $C_{\mathrm{An}}=$ anaerobic $\mathrm{C}$ metabolism rate, $P_{\text {An }}=$ proportion of non-nitrogenous end products of anaerobic metabolism oxidized, $N_{\mathrm{T}}=$ $\mathrm{N}$ mineralization rate, and $P_{\mathrm{N}}=$ proportion of mineralized $\mathrm{N}$ nitrified (molar $\mathrm{O}_{2}$ consumption is twice the nitrification rate; Froelich et al. 1979). The expected ratio of $O_{\mathrm{T}}$ to $\mathrm{CO}_{2}$ production $\left(O_{\mathrm{T}}: C_{\mathrm{T}}\right)$ can be obtained by dividing both sides of the equation by $C_{\mathrm{T}}$ :

$$
\frac{O_{\mathrm{T}}}{C_{\mathrm{T}}}=\frac{C_{\mathrm{Ox}}+C_{\mathrm{An}} P_{\mathrm{An}}}{C_{\mathrm{T}}}+\frac{2 N_{\mathrm{T}} P_{\mathrm{N}}}{C_{\mathrm{T}}}
$$

(autotrophic $\mathrm{CO}_{2}$ fixation by nitrification is inconsiderable at only 0.085 times the nitrification rate; Fenchel \& Blackburn 1979). $O_{\mathrm{T}}: C_{\mathrm{T}}$ is therefore a function both of the degree of oxidation of the reduced end products of respiration $\left(P_{\mathrm{An}}\right.$ and $\left.P_{\mathrm{N}}\right)$, and the $\mathrm{C}: \mathrm{N}$ ratio of the degrading organic matter $\left(N_{\mathrm{T}}: C_{\mathrm{T}}\right)$. For the degradation of Redfield organic matter (molar $\mathrm{C}: \mathrm{N}$ ratio $=6.6$ or $N_{\mathrm{T}}: C_{\mathrm{T}}$ ratio $\left.=0.15\right)$, the maximum possible value of the $O_{\mathrm{T}}: C_{\mathrm{T}}$ ratio is 1.3 , but export or storage of reduced metabolic products $\left(P_{\mathrm{An}}<1\right)$, or incomplete nitrification of remineralized $\mathrm{NH}_{4}{ }^{+}\left(P_{\mathrm{N}}<1\right)$, lowers the $O_{\mathrm{T}}$ : $C_{\mathrm{T}}$ ratio to below 1.3.

Similarly, in the salt marsh creek sediments we studied, the theoretical maximum of the $O_{\mathrm{T}}: C_{\mathrm{T}}$ ratio is 1.33 (from Eq. 2, since the $N_{\mathrm{T}}: C_{\mathrm{T}}$ ratio $=0.16$; Fig. 7A). Incomplete nitrification of mineralized $\mathrm{NH}_{4}{ }^{+}$ (46\%; Fig. 8C) would lower the theoretical ratio to 1.15. The measured ratio of 1.0 (Fig. 7B) therefore suggests incomplete oxidation of reduced end products, likely a net mineral sink for $\mathrm{S}^{2-}$ (King 1983). Similarly, in a review of 12 studies of $\mathrm{CO}_{2}$ and $\mathrm{O}_{2}$ fluxes in shallow marine sediments, 7 had $O_{\mathrm{T}}: C_{\mathrm{T}}$ ratios close to 1.0 , indicating a similar balance between $\mathrm{O}_{2}$ consumption by nitrification and incomplete oxidation of reduced end products (Tables $3 \& 4$ ). Of the remainder, 4 had ratios significantly less than 1.0, but 3 of these studies (Dollar et al. 1991, Hammond et al. 1999, Nicholson \& Longmore 1999) used less reliable alkalinity and $\mathrm{pH}$ values, rather than direct measurements to determine $\mathrm{CO}_{2}$ flux. As in other studies, individual measurements of $O_{\mathrm{T}}: C_{\mathrm{T}}$ ratios in the present study ranged widely (0.5 to 2.0). High autumn ratios suggest late-season oxidation of reduced sulfur metabolites accumulated during the summer, similar to those measured in other studies (Zimmerman \& Benner 1994, Giblin et al. 1997).

Three studies we reviewed (Zimmerman \& Benner 1994, Nielsen \& Glud 1996, Rysgaard et al. 1998) measured sediment C:N flux ratios with reliable methods (denitrification measured either by direct $\mathrm{N}_{2}$ flux or by isotope pairing methods, and $\mathrm{CO}_{2}$ flux measured directly). As in the present study, C:N flux ratios were usually lower than the molar $\mathrm{C}: \mathrm{N}$ ratio of associated sediment or seston (Table 3). These lower $\mathrm{C}: \mathrm{N}$ flux ratios suggest heterotrophic fractionation of the available organic material, with organic material of high $\mathrm{N}$ content (e.g. protein) being respired in preference to material of low $\mathrm{N}$ content (e.g. carbohydrate) (Buchsbaum et al. 1991, Giblin et al. 1997). In most studies, including ours, $\mathrm{C}: \mathrm{N}$ flux ratios were similar to the molar composition of Redfield organic

Table 3. Elemental flux ratios (molar) from shallow marine sediments. Means given, with ranges in parentheses. Dashes indicate data not collected. $\mathrm{O}_{2}: \mathrm{CO}_{2}$ flux ratio measured as $\mathrm{O}_{2}$ consumption/ $\mathrm{CO}_{2}$ production; $\mathrm{CO}_{2}: \mathrm{N}$ flux ratio measured as CO 2 production/N mineralization. Only studies measuring total remineralized $\mathrm{N}\left(\mathrm{NH}_{4}{ }^{+}+\mathrm{NO}_{\mathrm{x}}{ }^{-}+\mathrm{N}_{2}\right)$ were reviewed, with coupled nitrification-denitrification $\left(D_{n}\right)$ measured either with the direct $\mathrm{N}_{2}$ flux or the isotope pairing method (see Table 4 for method used)

\begin{tabular}{|c|c|c|c|c|c|}
\hline Environment & $\begin{array}{l}\text { Water } \\
\text { depth } \\
(\mathrm{m})\end{array}$ & $\mathrm{O}_{2}: \mathrm{CO}_{2}$ flux & $\begin{array}{l}\text { C:N content } \\
\text { (sediment } \\
\text { or seston) }\end{array}$ & $\mathrm{CO}_{2}: \mathrm{N}$ flux & Source \\
\hline Estuary & 4 & $0.45(0.4-0.5)$ & - & $7.9(6.4-9.4)$ & An \& Joye (2001) \\
\hline Estuary, bay ${ }^{\mathrm{a}}$ & $1-14$ & $1.1(0.6-1.8)$ & - & - & Berelson et al. (1998) \\
\hline Bay & $1-6$ & $0.43(0.26-0.69)$ & - & - & Dollar et al. (1991) \\
\hline Bay & $3.5-13$ & $1.0(0.5-1.2)$ & - & - & Giblin et al. (1997) \\
\hline Coastal & $10-40$ & $0.75(0.43-0.95)$ & - & - & Hammond et al. (1999) \\
\hline Bay & $0.5-2$ & $0.41(0.25-0.57)$ & - & - & Hargrave \& Phillips (1981) \\
\hline Vegetated salt marsh peat & $\begin{array}{l}\text { Exposed } \\
\text { by tides }\end{array}$ & 0.92 & - & - & Howes et al. (1984) \\
\hline Estuary & 0.3 & $0.98(0.97-0.98)$ & - & - & Kristensen \& Blackburn (1987) \\
\hline Bay & $9-24$ & $1.5(0.9-2.6)$ & - & - & Nicholson \& Longmore (1999) \\
\hline Bay & 16 & - & - & $6.6(4.4-9.7)$ & Nielsen \& Glud (1996) \\
\hline Arctic fjord & 50 & 1.0 & 11 & 15.6 & Rysgaard et al. (1998) \\
\hline Estuary & $2-3$ & $1.1(0.2-1.9)$ & $12.5(9.4-13.9)$ & $5.7(1.7-15.6)$ & Zimmerman \& Benner (1994) \\
\hline Salt marsh tidal creek & $<2$ & $1.0(0.5-2.0)$ & $10.5(7.5-14.7)$ & $6.1(5.0-7.0)$ & This study \\
\hline
\end{tabular}


Table 4. Contribution of nitrification and denitrification to sediment elemental cycling. Only studies measuring denitrification by direct $\mathrm{N}_{2}$ flux or by the isotope pairing method were reviewed. Means are given, with ranges in parentheses. Dashes indicate data not collected. $\mathrm{CO}_{2}$ production by denitrification was measured as total denitrification (coupled nitrification-denitrification, $D_{\mathrm{n}},+$ denitrification of water column nitrate, $D_{\mathrm{w}}$ )

\begin{tabular}{|c|c|c|c|c|c|c|c|}
\hline Environment & $\begin{array}{l}\text { Water } \\
\text { depth } \\
(\mathrm{m})\end{array}$ & $\begin{array}{l}\text { Nitrification } \\
\text { of remineral- } \\
\text { ized N (\%) }\end{array}$ & $\begin{array}{l}\mathrm{O}_{2} \text { consump- } \\
\text { tion by nitri- } \\
\text { fication }(\%)\end{array}$ & $\begin{array}{l}\text { Overlying } \\
\text { water } \\
\mathrm{NO}_{\mathrm{x}}^{-}(\mu \mathrm{M})\end{array}$ & $\begin{array}{c}D_{\mathrm{w}}:\left(D_{\mathrm{n}}+D_{\mathrm{w}}\right) \\
(\%)\end{array}$ & $\begin{array}{l}\mathrm{CO}_{2} \text { produc- } \\
\text { tion by de- } \\
\text { nitrification }(\%)\end{array}$ & Source \\
\hline Estuary & 4 & $79(59-100)$ & $48(42-53)$ & - & - & $12(12-13)$ & An \& Joye $(2001)^{a}$ \\
\hline Continental shelf & $30-640$ & $73(20-100)$ & $20(4-34)^{\mathrm{c}}$ & $\sim 26$ & $60(10-91)$ & - & Devol \& Christensen $(1993)^{a}$ \\
\hline Estuary, bay & $7-30$ & - & $12(3-33)$ & - & $11(0-39)$ & - & Seitzinger et al. $(1984)^{\mathrm{a}}$ \\
\hline Shallow lake & 1.6 & $46(17-64)$ & $23(6-38)$ & - & - & - & van Luijn et al. (1999) ${ }^{a}$ \\
\hline Shallow estuary & $<2$ & $57(41-80)$ & $23(9-52)$ & - & - & - & Yoon \& Benner $(1992)^{a}$ \\
\hline Estuary & $2-3$ & $77(10-100)$ & $38(2-61)$ & $16(0.3-49)$ & $17(0-104)$ & $26(0-75)$ & Zimmerman \& Benner $(1994)^{\mathrm{a}, \mathrm{d}}$ \\
\hline Shallow bay & $<2$ & $9(0-108)$ & $0.4(0-1.5)$ & $23(0-68)$ & $51(0-84)$ & - & Jensen et al. $(1996)^{b}$ \\
\hline Continental shelf & $<40$ & $64(41-93)$ & $14(9-18)$ & 1 & $5(2-6)$ & - & Lohse et al. $(1996)^{b}$ \\
\hline Bay & 16 & - & - & $4(0-8)$ & $12(0-26)$ & - & Nielsen \& Glud (1996) ${ }^{\mathrm{b}}$ \\
\hline Estuary & 1 & $55(50-60)$ & - & 107 & $83(83-84)$ & - & Rysgaard et al. (1993) \\
\hline Arctic fjord & 50 & 70 & 8.6 & 6 & 0 & 3.9 & Rysgaard et al. (1998) ${ }^{b}$ \\
\hline River, estuary ${ }^{\mathrm{e}}$ & $2-15$ & - & $7^{d}(0-7.5)$ & $(4-611)$ & $62(28-100)$ & - & Trimmer et al. (2000a) ${ }^{b}$ \\
\hline Estuary & $0-1$ & $52(0-170)$ & $12(0-40)$ & $24(1.6-76)$ & $54(4-100)$ & - & Trimmer et al. $(2000 b)^{b}$ \\
\hline Salt marsh tidal creek & $<2$ & $46(21-89)$ & $18(6-30)$ & $28(0-133)$ & $28(17-69)$ & $15(10-29)$ & This study ${ }^{\mathrm{a}}$ \\
\hline \multicolumn{4}{|c|}{$\begin{array}{l}\text { a Denitrification measured with } \mathrm{N}_{2} \text { flux method } \\
{ }^{\mathrm{b}} \text { Denitrification measured with isotope pairing method } \\
{ }^{\mathrm{c} O n e} \text { anomalously high point }(70 \%) \text { omitted }\end{array}$} & \multicolumn{4}{|c|}{$\begin{array}{l}{ }^{\mathrm{d}} \text { Paradoxically high }(<1 \text { or }>100 \%) \text { values omitted from mean } \\
{ }^{\mathrm{e}} \text { Multiple environment designations indicate a series of measure- } \\
\text { ments along a transect extending from one environment to another }\end{array}$} \\
\hline
\end{tabular}

matter. This apparent fractionation of the bulk organic matter suggests that stoichiometric estimations of denitrification should not rely on the C:N ratio of seston or sediment organic matter to estimate $D_{\mathrm{n}}$ as 'missing' $\mathrm{N}$ from measured $\mathrm{CO}_{2}$ and dissolved inorganic $\mathrm{N}$ fluxes.

\section{Contribution of nitrification-denitrification to elemental cycling}

Although $\mathrm{C}$ and oxygen (O) cycling by nitrifiers and denitrifiers could not be measured directly, it was estimated from the known stoichiometry of the associated metabolic pathways (Richards et al. 1965, Froelich et al. 1979) (Fig. 8). In the present study, nitrification contributed an average of $18 \%$ to total sediment $\mathrm{O}_{2}$ consumption (contribution of nitrification $=O_{\mathrm{N}}: O_{\mathrm{T}}$, where $O_{\mathrm{N}}$ is the oxygen consumption rate of nitrification and $O_{\mathrm{T}}$ is the total $\mathrm{O}_{2}$ consumption rate) (Fig. 8A). When $O_{\mathrm{T}}: C_{\mathrm{T}}=1.0$ (as in many studies; Table 3), a simplified expression for $O_{\mathrm{N}}: O_{\mathrm{T}}$ can be derived from Eqs. (1) \& (2):

$$
\frac{O_{\mathrm{N}}}{O_{\mathrm{T}}}=\frac{2 N_{\mathrm{T}} P_{\mathrm{N}}}{C_{\mathrm{T}}}
$$

The maximum value of the $O_{\mathrm{N}}: O_{\mathrm{T}}$ ratio for Redfield matter would then be $30 \%\left(P_{\mathrm{N}}=1 ; N_{\mathrm{T}}: C_{\mathrm{T}}=\right.$ $0.15)$; Lower values would be expected with incomplete nitrification $\left(P_{\mathrm{N}}<1\right)$. As expected, $O_{\mathrm{N}}$ : $O_{\mathrm{T}}$ ratios in the salt-marsh creek sediments of the present study were within the theoretical range (4 to $30 \%$ ), with the mean $(18 \%)$ corresponding to that expected from Eq. (3) $\left(P_{\mathrm{N}}=46 \%\right.$ [Fig. 8C], $N_{\mathrm{T}}$ : $C_{\mathrm{T}}$ ratio $=0.16$ [Fig. 7A]). Other studies of shallow coastal marine systems also found $O_{\mathrm{N}}: O_{\mathrm{T}}$ ratios (recalculated from published data) ranging from 0 to $30 \%$ (Table 4, Fig. 9). Similarly, $O_{\mathrm{N}}: O_{\mathrm{T}}$ in continental shelf sediments ranged from 4 to $34 \%$ (Devol \& Christensen 1993, Lohse et al. 1996). The relationship between $P_{\mathrm{N}}$ and the $O_{\mathrm{N}}: O_{\mathrm{T}}$ ratio suggested by Eq. (3) was supported by the data of the present study ( $\mathrm{r}=0.95, \mathrm{n}=15$; $\mathrm{p}<$ 0.001 ), with nitrification accounting for a maximum of $28 \%$ of total $\mathrm{O}_{2}$ flux when $89 \%$ of mineralized $\mathrm{N}$ was nitrified (Fig. 9). Similar relationships were found in other shallow systems where data was available (shown in Fig. 9), though the relationship in the continental shelf system was poor $(\mathrm{r}=0.34$; Devol \& Christensen 1993), and in another study (Zimmerman \& Benner 1994), some $O_{\mathrm{N}}: O_{\mathrm{T}}$ ratios above $30 \%$ were found to be associated with very low $C_{\mathrm{T}}: N_{\mathrm{T}}$ flux ratios $(<5)$.

The contribution of $D_{\mathrm{n}}$ to C cycling can be expressed by the following equation:

$$
\frac{C_{\mathrm{D}}}{C_{\mathrm{T}}}=\frac{1.25 N_{\mathrm{T}} P_{\mathrm{D}}}{C_{\mathrm{T}}}
$$

where $C_{\mathrm{D}}=$ the $\mathrm{CO}_{2}$ production rate of denitrification and $P_{\mathrm{D}}=$ the proportion of mineralized $\mathrm{N}$ denitrified (Richards et al. 1965). This expression has a maxi- 


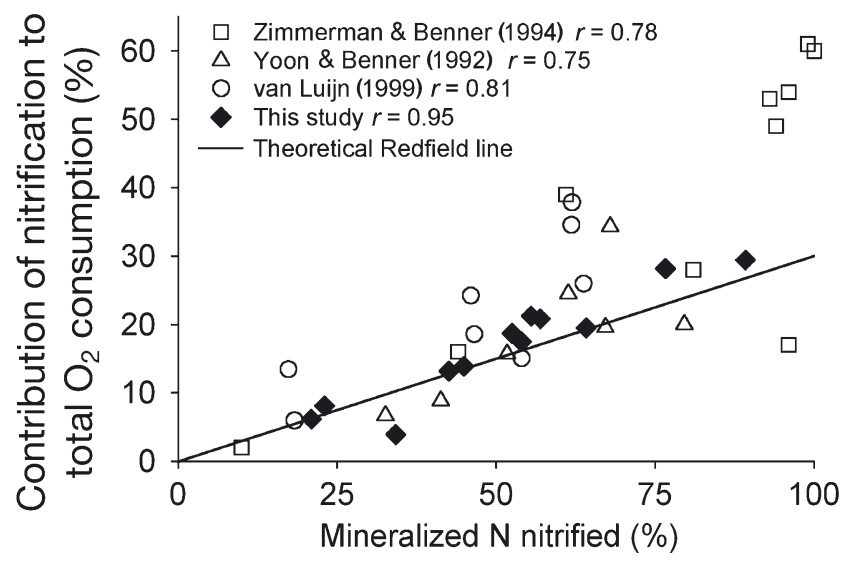

Fig. 9. Relationship between contribution of nitrification to total $\mathrm{O}_{2}$ consumption $\left(O_{\mathrm{N}}: O_{\mathrm{T}}\right)$ and the proportion of mineralized $\mathrm{N}$ nitrified $\left(P_{\mathrm{N}}\right)$ in shallow sediments. Most points lie close to the theoretical line expected for respiration of Redfield organic matter and $O_{\mathrm{T}}: C_{\mathrm{T}}=1.0$ (recalculated from sources: Yoon \& Benner 1992 [n = 7; $\mathrm{p}=0.05]$, Zimmerman \& Benner 1994 [ $\mathrm{n}=10 ; \mathrm{p}<0.001]$, van Luijn et al. $1999[\mathrm{n}=8 ; \mathrm{p}=0.01])$

mum Redfield value of $18 \%\left(P_{\mathrm{D}}=1 ; N_{\mathrm{T}}: C_{\mathrm{T}}=0.15\right)$. Carbon cycling resulting from $D_{\mathrm{n}}$ in the present study averaged $10 \%$ of the total cycling of sediment C $\left(\mathrm{CO}_{2}\right.$ production by denitrification-autotrophic $\mathrm{CO}_{2}$ fixation by nitrification $=11-1 \%$ ). The further contribution of $D_{\mathrm{w}}$ increased the total to $15 \%$, similar to the contribution of nitrification to the $\mathrm{O}_{2}$ cycle. Although an early study of a Danish estuary found that denitrification accounted for only 3 to $4 \%$ of sediment C cycling (Jørgensen \& Sørensen 1985), the acetylene block assay they used is known to underestimate denitrification rates (Seitzinger et al. 1993). In other studies using either $\mathrm{N}_{2}$ flux or ${ }^{15} \mathrm{~N}$ isotope pairing methods, and measuring total $\left(D_{\mathrm{n}}+D_{\mathrm{w}}\right)$ denitrification, mean $C_{\mathrm{D}}$ : $C_{\mathrm{T}}$ ranged from $3.9 \%$ in an Arctic fjord (Rysgaard et al. 1998), to $12 \%$ in a Texas estuary (An \& Joye 2001), with even higher values (up to $75 \%$, associated high water column $\mathrm{NO}_{\mathrm{x}}^{-}$concentrations) in another Texas estuary (Zimmerman \& Benner 1994).

An average of $46 \%$ (21 to $89 \%$ ) of the $\mathrm{NH}_{4}{ }^{+}$remineralized in Mashapaquit Marsh tidal creek sediments was nitrified and denitrified, typical for estuaries and coastal marine sediments (Table 4). In some estuaries, $D_{\mathrm{n}}$ is not limited by the supply of $\mathrm{NO}_{\mathrm{x}}{ }^{-}$through nitrification (Seitzinger 1987). However, in the present study, the absence of $\mathrm{NO}_{\mathrm{x}}{ }^{-}$fluxes from the sediments indicate that nitrification limited $D_{\mathrm{n}}$, possibly because high $\mathrm{N}$ inputs to the marsh drove high organic $\mathrm{C}$ production, which limited $\mathrm{O}_{2}$ availability to nitrifiers while creating favorable conditions for denitrification (van Luijn et al. 1999).

\section{Controls on sediment metabolism}

Both $\mathrm{O}_{2}$ consumption and $\mathrm{CO}_{2}$ production were equally correlated with both temperature and sediment C (Figs. 4 \& 5). In contrast, $D_{\mathrm{n}}$ was controlled primarily by sediment $C$ concentration (within sediment types) and lability (between sediment types), but was poorly correlated with temperature (Figs. 4C \& 5C). $D_{\mathrm{w}}$ was controlled by water column $\mathrm{NO}_{\mathrm{x}}^{-}$(Fig. 6A inset; Smith 1999) within the range of concentrations found in the tidal creek $(<133 \mu \mathrm{M}$, Table 1$)$. However, when $\mathrm{NO}_{3}{ }^{-}$was not limiting (i.e. at experimental concentrations of $500 \mu \mathrm{M}$ ), $D_{\mathrm{w}}$ was, like $D_{\mathrm{n}}$, limited by sediment $\mathrm{C}$ concentration (within sites) and lability (between sites) (Fig. 5D).

Spring maxima for denitrification indicate the predominance of seasonal factors other than temperature in controlling metabolism (i.e. spring algal blooms) (Jørgensen \& Sørensen 1985, Nowicki et al. 1999). In contrast, our late-summer maximum may support the predominance of temperature-driven seasonal effects in this salt marsh creek bottom. Although temperature appeared to account for a significant proportion of the variability in $\mathrm{O}_{2}$ and $\mathrm{CO}_{2}$ fluxes, it was not possible to separate temperature from other seasonal effects. In the sandy sediments, organic $\mathrm{C}$ content was significantly correlated with temperature $(r=0.57)$, suggesting a seasonal component to the availability of $\mathrm{C}$ in these sediments. It is also likely that seasonal cycles of algal production had an effect on the lability of sediment $\mathrm{C}$ pools. Other seasonal effects on metabolism that could be confounded with temperature include benthic irrigation and sediment redox state. Nonetheless, if the temperature effects were direct, $Q_{10}$ values for $\mathrm{O}, \mathrm{C}$, and $\mathrm{N}$ metabolism in the salt marsh creek sediments of the present study would range from 1.6 to 2.0 , similar to those reported in the literature for estuarine sediments $\left(Q_{10}\right.$ for $\mathrm{O}_{2}$ consumption $=2.7$, Jørgensen \& Sørensen 1985; $Q_{10}$ for denitrification $=2.1$, Zimmerman \& Benner 1994).

Within each sediment type, metabolic rates were related to sediment $\mathrm{C}$ concentrations, but the sediment $\mathrm{C}$ quality of the 2 sediment types differed (Fig. 5, Table 2). Organic material at the sandy site was about twice as reactive as at the muddy site, though half as concentrated, and $\mathrm{O}_{2}, \mathrm{CO}_{2}$, and $D_{\mathrm{n}}$ did not significantly differ between the sites. Fresh algal $\mathrm{C}$ likely accounted for more than 4 times as much of the sediment $\mathrm{C}$ in sandy sediments than muddy sediments. However, $\mathrm{C}: \mathrm{N}$ flux ratios and the isotopic composition of sediment $\mathrm{C}$ in both sediment types were similar, indicating a similar source of organic $C$ for respiration. Nevertheless, the relationship of sediment $C$ content to metabolic activity in the 2 sediment types (Fig. 5C) suggests that the $\mathrm{C}$ pool of muddy sediments contained a sig- 
nificant fraction of refractory material. Although the regression lines for sandy sediments intercept the $x$-axis near 0 , in muddy sediments $D_{\mathrm{n}}$ decreases to 0 at $0.7 \mathrm{mmol} \mathrm{C} \mathrm{cm}^{-3}$.

In systems where planktonic production dominates, production and deposition control sediment $\mathrm{C}$ content, resulting in muddy or sandy sediments. Studies have generally found lower metabolic rates in sandy sediments (Jørgensen \& Sørensen 1985, Jensen et al. 1996, Trimmer et al. 2000a). However, in the shallow waters of the salt marsh tidal creek, benthic production dominates, and sediment $\mathrm{C}$ content was likely controlled by in situ benthic production. Sandy sediments were most often found below groundwater seepage faces (our Fig. 1, Smith 1999), and production in the sandy sediments may have been stimulated by nutrient-rich groundwater fluxes. However, heterotrophic metabolism was equal at both sites, although sandy sediment $\mathrm{C}$ pools were lower, suggesting that sandy sediments may have been depleted of organic matter by eroding effects of groundwater intrusion (Redfield 1972, Howes et al. 1996).

\section{Fate of groundwater nitrate}

Our study suggests that benthic microalgae were the primary source of the sediment organic material that drove creek-bottom respiration and $D_{\mathrm{n}}$. In this shallow (<1.2 m) system, phytoplankton likely contributed little to total production. In addition, organic matter influxes through tidal water were small, and the overall balance was toward export from the marsh (Smith 1999). Export of macrophytic plant material from the vegetated marsh to tidal creek sediments in similar marsh systems is also known to be small (Wolaver et al. 1983, White \& Howes 1994a). The isotopic composition of organic C in Mashapaquit Marsh tidal creek sediments was depleted in ${ }^{13} \mathrm{C}$ relative to vegetated marsh sources and benthic macroalgae. Sediment $\delta^{13} \mathrm{C}$ levels were, however, similar to values reported for salt marsh creek benthic microalgae (Haines 1976, Sullivan \& Moncreiff 1990). Stable isotope analyses in other salt marshes have also identified benthic microalgae as the dominant contributors to tidal sediment organic matter (Sullivan \& Moncreiff 1990, Page 1997, Boschker et al. 1999).

Identification of the size of $\mathrm{N}$ sources to the tidal creeks also suggests that groundwater $\mathrm{NO}_{\mathrm{x}}{ }^{-}$was the dominant $\mathrm{N}$ source driving benthic algal production. Groundwater represents an $\mathrm{N}$ load to the tidal sediments of $32 \mathrm{mmol} \mathrm{m}^{-2} \mathrm{~d}^{-1}$ (Smith 1999). In contrast, $\mathrm{N}$ inputs from other sources were likely much lower. Precipitation $\mathrm{N}$ inputs in a nearby marsh were only $0.11 \mathrm{mmol} \mathrm{m}^{-2} \mathrm{~d}^{-1}$ (Valiela \& Teal 1979), while $\mathrm{N}$ fixa- tion accounted for a maximum of $0.32 \mathrm{mmol} \mathrm{m}^{-2} \mathrm{~d}^{-1}$ (Teal et al. 1979). Inputs from the vegetated marsh were likely less than $1.1 \mathrm{mmol} \mathrm{m}^{-2} \mathrm{~d}^{-1}$ (recalculated from White \& Howes 1994b), while tidal N exchanges represented a net loss (Smith 1999). Groundwater N inputs to the tidal creek were therefore more than 20 times as great as all other inputs combined. A significant algal sink for this groundwater $\mathrm{N}$ is further supported by the $\mathrm{N}$ budget of the marsh (Smith 1999), which showed that $12.9 \mathrm{mmol} \mathrm{N} \mathrm{m}^{-2} \mathrm{~d}^{-1}$ were removed from groundwater during passage through the marsh. Only 24 to $34 \%$ of this missing $N$ could be accounted for by in situ measurements of $D_{\mathrm{w}}$. The remainder (66 to $76 \%$ ) may have been assimilated by benthic algae, and eventually lost from the marsh indirectly through $D_{\mathrm{n}}$. This partitioning of $\mathrm{N}$ losses between $D_{\mathrm{w}}$ and $D_{\mathrm{n}}$ was supported by the results of the present study, where $D_{\mathrm{w}}$ accounted for $28 \%$ of total denitrification N losses from the tidal creek sediments, with the remainder $(72 \%)$ accounted for by $D_{n}$, or denitrification losses of $\mathrm{N}$ released during the degradation of algal organic material.

The dominance of $D_{\mathrm{n}}$ in Mashapaquit Marsh was greater than that found in other coastal environments with similar water column $\mathrm{NO}_{\mathrm{x}}^{-}$concentrations (Table 4). The dominance of $D_{\mathrm{n}}$ in the shallow marsh creek may have resulted from strong benthic algal competition for $\mathrm{NO}_{\mathrm{x}}{ }^{-}$, which reduced the availability of $\mathrm{NO}_{\mathrm{x}}^{-}$for $D_{\mathrm{w}}$. Nevertheless, the high metabolic activity of this algal material resulted in the eventual loss of much of its $\mathrm{N}$ through $D_{\mathrm{n}}$. The important role that benthic algae play in the sediment $\mathrm{N}$ cycle of Mashapaquit Marsh contrasts with tidal creek sediments in nearby Great Sippewissett Marsh, which are narrow and shaded by Spartina alterniflora plants, and where sediment pigment levels were $\sim 10$ times lower than in Mashapaquit Marsh (Wiltse et al. 1984). It is likely that the balance of competition for water column $\mathrm{NO}_{\mathrm{x}}{ }^{-}$ between algae and denitrifiers is shifted in favor of algae in the shallow, unshaded, wide tidal channel of Mashapaquit Marsh, but shifts toward denitrifiers in narrow, shaded tidal creeks or deeper aquatic systems.

\section{Denitrification in shallow coastal sediments}

$D_{\mathrm{n}}$ rates measured in this study (mean 5.2, range 0.2 to $12.6 \mathrm{mmol} \mathrm{N} \mathrm{m}^{-2} \mathrm{~d}^{-1}$; Table 1) were at the high end of the range reported for estuarine sediments (Jenkins \& Kemp 1984, Jørgensen \& Sørensen 1985, Seitzinger 1987, Jensen et al. 1996), although rates of up to $5.0 \mathrm{mmol} \mathrm{N} \mathrm{m}{ }^{-2} \mathrm{~d}^{-1}$ have also been reported from an unpolluted Florida estuary (Seitzinger 1987). Nevertheless, high denitrification rates are most often found in systems receiving high $\mathrm{N}$ loads and in sediments 
with high organic C contents (Jørgensen \& Sørensen 1985). At the upper end, denitrification rates as high as $197 \mathrm{mmol} \mathrm{N} \mathrm{m}{ }^{-2} \mathrm{~d}^{-1}$ have been measured in sediments near a sewage outfall (Trimmer et al. 2000a). Two studies besides ours report denitrification fluxes for embayments in Cape Cod, Massachusetts. Nowicki et al. (1999) found very low rates, ranging from 0.05 to $0.58 \mathrm{mmol} \mathrm{N} \mathrm{m} \mathrm{N}^{-2} \mathrm{~d}^{-1}$, in an estuary (Towns Cove) receiving $2.1 \mathrm{mmol} \mathrm{N} \mathrm{m} \mathrm{N}^{-2} \mathrm{~d}^{-1}$ from the surrounding watershed (Giblin \& Gaines 1990). However, denitrification rates in a similar system (Childs River) receiving similar $\mathrm{N}$ loads to Mashapaquit Marsh $\left(35 \mathrm{mmol} \mathrm{N} \mathrm{m}^{-2}\right.$ $\mathrm{d}^{-1}$; Valiela et al. 1992) averaged $3.3 \mathrm{mmol} \mathrm{N} \mathrm{m} \mathrm{N}^{-2} \mathrm{~d}^{-1}$ (Lamontagne \& Valiela 1995), similar to those of the present study.

High groundwater $\mathrm{NO}_{\mathrm{x}}{ }^{-}$loads to the creek-bottom sediments of Mashapaquit Marsh likely support high benthic-algal production and high sediment concentrations of labile organic matter. Degradation of this organic material supports high rates of $\mathrm{O}_{2}, \mathrm{CO}_{2}$, and $\mathrm{N}$ cycling, including denitrification of water column $\mathrm{NO}_{\mathrm{x}}^{-}$ and nearly half of the remineralized N. $D_{\mathrm{w}}$ contributes significantly to total denitrification $(28 \%)$. Denitrification is a significant contributor to the total metabolism of these salt marsh sediments, contributing 15 and $18 \%$ to the total cycling of $\mathrm{C}$ and $\mathrm{O}$, respectively.

Acknowledgements. We thank D. Cook and S. Cook for access to their salt marsh property. K. Smith (SEA Consultants, Cambridge, Massachusetts) contributed sediment data. Analytical and field support was supplied by K. Smith, M. Jull, P. Henderson (SMAST), and numerous interns and volunteers. The advice of C. Taylor and the comments of 2 anonymous reviewers improved the manuscript. Financial support for this work was provided by the Coastal Systems Program at the School for Marine Science and Technology (SMAST) and by the Education Department of the Woods Hole Oceanographic Institution.

\section{LITERATURE CITED}

An S, Joye SB (2001) Enhancement of coupled nitrificationdenitrification by benthic photosynthesis in shallow estuarine sediments. Limnol Oceanogr 46:62-74

Berelson WM, Heggie D, Longmore A, Kilgore T, Nicholson G, Skyring G (1998) Benthic nutrient recycling in Port Phillip Bay, Australia. Estuar Coast Shelf Sci 46:917-934

Boschker HTS, de Brouwer JFC, Cappenberg TE (1999) The contribution of macrophyte-derived organic matter to microbial biomass in salt-marsh sediments: stable carbon isotope analysis of microbial biomarkers. Limnol Oceanogr 44:309-319

Buchsbaum R, Valiela I, Swain T, Dzierzeski M, Allen S (1991) Available and refractory nitrogen in detritus of coastal vascular plants and macroalgae. Mar Ecol Prog Ser 72: 131-143

Devol AH, Christensen JP (1993) Benthic fluxes and nitrogen cycling in sediments of the continental margin of the eastern North Pacific. J Mar Res 51:345-372
Dollar SJ, Smith SV, Vink SM, Obrebski S, Hollibaugh JT (1991) Annual cycle of benthic nutrient fluxes in Tomales Bay, California, and contribution of the benthos to total ecosystem metabolism. Mar Ecol Prog Ser 79:115-125

Fenchel T, Blackburn TH (1979) Bacteria and mineral cycling. Academic Press, New York

Froelich PN, Klinkhammer GP, Bender ML, Luedtke GR and 6 others (1979) Early oxidation in pelagic sediments of the eastern equatorial Atlantic: suboxic diagenesis. Geochim Cosmochim Acta 43:1075-1090

Fujita RM, Wheeler PA, Edwards RL (1989) Assessment of macroalgal nitrogen limitation in a seasonal upwelling region. Mar Ecol Prog Ser 53:293-303

Giblin AE, Gaines AG (1990) Nitrogen inputs to a marine embayment: the importance of groundwater. Biogeochemistry 10:309-328

Giblin AE, Hopkinson CS, Tucker J (1997) Benthic metabolism and nutrient cycling in Boston Harbor, Massachusetts. Estuaries 20:346-364

Haines EB (1976) Stable carbon isotope ratios in the biota, soils and tidal waters of a Georgia salt marsh. Estuar Coast Mar Sci 4:609-616

Hammond DE, Giordani P, Berelson WM, Poletti R (1999) Diagenesis of carbon and nutrients and benthic exchange in sediments of the Northern Adriatic Sea. Mar Chem 66: 53-79

Hargrave BT, Phillips GA (1981) Annual in situ carbon dioxide and oxygen flux across a subtidal marine sediment. Estuar Coast Shelf Sci 12:725-737

Harvey JW, Odum WE (1990) The influence of tidal marshes on upland groundwater discharge to estuaries. Biogeochemistry 10:217-236

Havens KE, Hauxwell J, Tyler AC, Thomas S and 5 others (2001) Complex interactions between autotrophs in shallow marine and freshwater ecosystems: implications for community responses to nutrient stress. Environ Pollut 113:95-107

Howes BL, Dacey JWH, King GM (1984) Carbon flow through oxygen and sulfate reduction pathways in salt marsh sediments. Limnol Oceanogr 29:1037-1051

Howes BL, Dacey JWH, Teal JM (1985) Annual carbon mineralization and belowground production of Spartina alterniflora in a New England salt marsh. Ecology 66:595-605

Howes BL, Weiskel PK, Goehringer DD, Teal JM (1996) Interception of freshwater and nitrogen transport from uplands to coastal waters: the role of saltmarshes. In: Nordstrom KF, Roman CT (eds) Estuarine shores: evolution, environments and human alterations. John Wiley and Sons, New York, p 287-310

Jenkins MC, Kemp WM (1984) The coupling of nitrification and denitrification in two estuarine sediments. Limnol Oceanogr 29:609-619

Jensen KM, Jensen MH, Kristensen E (1996) Nitrification and denitrification in Wadden Sea sediments (Konigshafen, Island of Sylt, Germany) as measured by nitrogen isotope pairing and isotope dilution. Aquat Microb Ecol 11:181-191

Jørgensen BB (1982) Mineralization of organic matter in the sea bed: the role of sulphate reduction. Nature 296: $643-645$

Jørgensen BB, Sørensen J (1985) Seasonal cycles of $\mathrm{O}_{2}, \mathrm{NO}_{3}{ }^{-}$, and $\mathrm{SO}_{4}{ }^{-2}$ reduction in estuarine sediments: the significance of an $\mathrm{NO}_{3}^{-}$reduction maximum in spring. Mar Ecol Prog Ser 24:65-74

King GM (1983) Sulfate reduction in Georgia salt marsh soils: an evaluation of pyrite formation using ${ }^{35} \mathrm{~S}$ and ${ }^{55} \mathrm{Fe}$ tracers. Limnol Oceanogr 28:987-995 
Kristensen E, Blackburn TH (1987) The fate of organic carbon and nitrogen in experimental marine sediment systems: influence of bioturbation and anoxia. J Mar Res 45: 231-257

Lamontagne MG, Valiela I (1995) Denitrification measured by a direct $\mathrm{N}_{2}$ flux method in sediments of Waquoit Bay, MA. Biogeochemistry 31:63-83

Lohse L, Kloosterhuis HT, van Raaphorst W, Helder W (1996) Denitrification rates as measured by the isotope pairing method and by the acetylene inhibition technique in continental shelf sediments of the North Sea. Mar Ecol Prog Ser 132:169-179

Nicholson GJ, Longmore AR (1999) Causes of observed temporal variability of nutrient fluxes from a southern Australian marine embayment. Mar Freshw Res 50:581-588

Nielsen LP, Glud RN (1996) Denitrification in a coastal sediment measured in situ by the nitrogen isotope pairing technique applied to a benthic flux chamber. Mar Ecol Prog Ser 137:181-186

Nowicki BL (1994) The effect of temperature, oxygen, salinity, and nutrient enrichment on estuarine denitrification rates measured with a modified nitrogen gas flux technique. Estuar Coast Shelf Sci 38:137-156

Nowicki BL, Requintina E, van Keuren D, Portnoy J (1999) The role of sediment denitrification in reducing groundwater-derived nitrate inputs to Nauset Marsh Estuary, Cape Cod, Massachusetts. Estuaries 22:245-259

Page HM (1997) Importance of vascular plant and algal production to macro-invertebrate consumers in a southern California salt marsh. Estuar Coast Shelf Sci 45:823-834

Redfield AC (1934) On the proportions of organic derivatives in seawater and their relation to the composition of plankton. In: Daniel R (ed) James Johnstone memorial volume. University Press, Liverpool, p 176-192

Redfield AC (1972) Development of a New England salt marsh. Ecol Monogr 42:937-942

Richards FA, Cline JD, Broenkow WW, Atkinson LP (1965) Some consequences of the decomposition of organic matter in Lake Nitinat, an anoxic fjord. Limnol Oceanogr 10(Suppl):R185-201

Rysgaard S, Risgaard-Petersen N, Nielsen LP, Revsbech NP (1993) Nitrification and denitrification in lake and estuarine sediment measured by the ${ }^{15} \mathrm{~N}$ dilution technique and isotope pairing. Appl Environ Microbiol 59:2093-2098

Rysgaard S, Thamdrup B, Risgaard-Petersen N, Fossing H, Berg P, Christensen PB, Dalsgaard T (1998) Seasonal carbon and nutrient mineralization in a high-Arctic coastal marine sediment, Young Sound, Northeast Greenland. Mar Ecol Prog Ser 175:261-276

Scheiner D (1976) Determination of ammonia and Kjeldahl N by indophenol method. Water Res 10:31-36

Seitzinger SP (1987) Nitrogen biogeochemistry in an unpolluted estuary: the importance of benthic denitrification. Mar Ecol Prog Ser 41:177-186

Seitzinger SP, Nixon SW, Pilson MEQ (1984) Denitrification and nitrous oxide production in a coastal marine ecosystem. Limnol Oceanogr 29:73-83

Seitzinger SP, Nielsen LP, Caffrey J, Christensen PB (1993) Denitrification measurements in aquatic sediments: a comparison of three methods. Biogeochemistry 23:147-167

Sewell PL (1982) Urban groundwater as a possible nutrient source for an estuarine benthic algal bloom. Estuar Coast Shelf Sci 15:569-576

Smith KN (1999) Salt marsh uptake of watershed nitrate. MA thesis, Boston University

Editorial responsibility: Victor de Jonge (Contributing

Editor), Haren, The Netherlands
Sullivan ML, Daiber FC (1974) Response in production of cordgrass, Spartina alterniflora, to inorganic nitrogen and phosphorus fertilizer. Chesap Sci 15:121-123

Sullivan ML, Moncreiff CA (1990) Edaphic algae are an important component of salt marsh food-webs: evidence from multiple stable isotope analyses. Mar Ecol Prog Ser 62:149-159

Teal JM (1962) Energy flow in the salt marsh ecosystem of Georgia. Ecology 43:614-624

Teal JM, Valiela I, Berlo D (1979) Nitrogen fixation by rhizosphere and free-living bacteria in salt marsh sediments. Limnol Oceanogr 24:126-132

Trimmer M, Nedwell DB, Sivyer DB, Malcolm SJ (2000a) Seasonal benthic organic matter mineralization measured by oxygen uptake and denitrification along a transect of the inner and outer River Thames estuary, UK. Mar Ecol Prog Ser 197:103-119

Trimmer M, Nedwell DB, Sivyer DB, Malcolm SJ (2000b) Seasonal organic mineralisation and denitrification in intertidal sediments and their relationship to the abundance of Enteromorpha sp. and Ulva sp. Mar Ecol Prog Ser 203: $67-80$

Valiela I, Teal JM (1974) Nutrient limitation in salt marsh vegetation. In: Reimold RJ, Green WH (eds) Ecology of halophytes. Academic Press, New York, p 547-563

Valiela I, Teal JM (1979) The nitrogen budget of a salt marsh ecosystem. Nature 280:652-656

Valiela I, Costa J, Foreman K, Teal JM, Howes B, Aubrey D (1990) Transport of groundwater-borne nutrients from watersheds and their effects on coastal waters. Biogeochemistry 10:177-197

Valiela I, Foreman K, LaMontagne M, Hersh D and 8 others (1992) Couplings of watersheds and coastal waters: sources and consequences of nutrient enrichment in Waquoit Bay, Massachusetts. Estuaries 15:443-457

van Luijn F, Boers PCM, Lijklema L, Sweerts JPRA (1999) Nitrogen fluxes and processes in sandy and muddy sediments from a shallow eutrophic lake. Water Res 33:33-42

Weiskel PK, DeSimone LA, Howes BL (1996) Transport of wastewater nitrogen and phosphorus through a coastal watershed. Environ Sci Technol 26:352-360

White DS, Howes BL (1994a) Long-term ${ }^{15} \mathrm{~N}$-nitrogen retention in the vegetated sediments of a New England salt marsh. Limnol Oceanogr 39:1878-1892

White DS, Howes BL (1994b) Translocation, remineralization, and turnover of nitrogen in the roots and rhizomes of Spartina alterniflora (Gramineae). Am J Bot 81:1225-1234

Wiltse WI, Foreman KH, Teal JM, Valiela I (1984) Effects of predators and food resources on the macrobenthos of salt marsh creeks. J Mar Res 42:923-942

Wolaver TG, Zieman JC, Wetzel R, Webb KL (1983) Tidal exchange of nitrogen and phosphorus between a mesohaline vegetated marsh and the surrounding estuary in the Lower Chesapeake Bay. Estuar Coast Shelf Sci 16: 321-332

Wood E, Armstrong F, Richards F (1967) Determination of nitrate in sea water by cadmium copper reduction to nitrite. J Mar Biol Assoc UK 47:23-31

Yoon WB, Benner R (1992) Denitrification and oxygen consumption in sediments of two south Texas estuaries. Mar Ecol Prog Ser 90:157-167

Zimmerman AR, Benner R (1994) Denitrification, nutrient regeneration and carbon mineralization in sediments of Galveston Bay, Texas, USA. Mar Ecol Prog Ser 114: 275-288

Submitted: December 12, 2002; Accepted: May 28, 2003

Proofs received from author(s): September 30, 2003 